\title{
India: Why Fiscal Adjustment Now
}

\author{
Brian Pinto and Farah Zahir ${ }^{1}$
}

\begin{abstract}
India's growth performance has been impressive over the last two decades. But its sustainability has been in question, first with the 1991 fiscal-balance of payments crisis (BoP), and then again after 1997/98, when fiscal deficits returned to the 10 percent of GDP range and government debt grew. This paper analyzes the deterioration in India's public finances and presents evidence suggesting that, in the absence of a fiscal adjustment, low inflation and high reserves may have been pursued at the expense of long-run growth and poverty reduction. Resolving this inflationexternal vulnerability-growth policy trilemma requires fiscal adjustment. In making its case, the paper shows, first, that fiscal fundamentals have weakened after 1997/98 even when compared with the pre-1991 crisis period. This has continued in spite of the recent record lows in interest rates. Second, the fiscal stance is not conducive to long-run growth and poverty reduction because capital spending has been cut to accommodate higher interest payments and other current spending, with expenditures on the social sectors stagnating. Third, without a fiscal adjustment, the debt burden is likely to reach unmanageable levels by the end of the Tenth Plan period. In contrast, a phased adjustment beginning now and focusing on a relatively small set of reforms is likely to improve debt dynamics substantially over the same horizon, while also promoting faster growth and poverty reduction.
\end{abstract}

World Bank Policy Research Working Paper 3230, March 2004

The Policy Research Working Paper Series disseminates the findings of work in progress to encourage the exchange of ideas about development issues. An objective of the series is to get the findings out quickly, even if the presentations are less than fully polished. The papers carry the names of the authors and should be cited accordingly. The findings, interpretations, and conclusions expressed in this paper are entirely those of the authors. They do not necessarily represent the view of the World Bank, its Executive Directors, or the countries they represent. Policy Research Working Papers are available online at http://econ.worldbank.org.

\footnotetext{
${ }^{1}$ Both authors are at the World Bank. We are grateful to Michael Carter and Sadiq Ahmed for encouraging us to write this paper. It liberally draws on India - Sustaining Reform, Reducing Poverty, a World Bank Development Policy Review released in July 2003. In revision, the paper has benefited substantially from comments from the peer reviewers Shantayanan Devarajan, Kalpana Kochhar, Mihir Rakshit and Suresh Tendulkar. Helpful comments were also received from Ijaz Nabi and Stephen Howes.
} 


\section{Introduction}

India's economic growth accelerated in the second half of the 1980s along with rising fiscal imbalances. The latter spilled over into current account deficits, depleting reserves and leading to a balance-of-payments (BOP) crisis in 1991. As part of the program of stabilization and structural reform that followed the crisis, customs and excise duties were cut and taxes on financial intermediation lowered with the object of creating more competitive and efficient real and financial sectors. This marked a break with decades of protection and financial repression. The fiscal deficit was also cut and the capital account partially liberalized to attract foreign portfolio and direct investment. As a result of these reforms, the economy grew rapidly and fiscal and government debt indicators improved dramatically during the five years 1992/93-1996/97, which coincided with the Eighth Plan period. But during the Ninth Plan period 1997/98-2001/02, growth slowed and fiscal deficits went back to their pre-1991 crisis levels, raising concern about the slowing pace of fiscal and structural reform. ${ }^{2}$ Government debt grew rapidly as revenues fell and interest payments climbed, although inflation and interest rates started falling in line with global trends toward the end of this period. Annex 1 contains background material on the 1991 crisis and summarizes studies on government debt sustainability through the 1990s.

Looking back over the last two decades, India's macroeconomic report card has been mixed. Its growth performance during the 1980s was exceeded by only 9 out of 123 countries, and that during the 1990 s by just 19 out of 137 countries. ${ }^{3}$ But India has also ranked high on fiscal deficits. In 2000, out of 74 countries with a population exceeding 10 million, only 7 had general government fiscal deficits exceeding 7 percent of GDP. India was one of them and only Turkey and Zimbabwe had higher deficits. ${ }^{4}$ Ahluwalia (2002a) presents data showing that India's fiscal and debt indicators are comparable to or worse than those of Argentina, Brazil and Turkey, countries that have actually experienced a serious recent macroeconomic crisis. He nevertheless concludes that India is not vulnerable to an external crisis in view of its build up of foreign exchange reserves, capital controls, flexible exchange rate system and widespread public ownership of banks. This stands in contrast to 1991, when India suffered a fiscal-BoP crisis with fiscal deficits of comparable size but much lower debt. What has changed is the reserve build-up. But does this mean that concern about the fiscal stance is misplaced?

No, for three key reasons. The first is that even though growth rose from a 3.5 percent trend rate over the previous three decades to close to 6 percent over the 1980s and 1990s, this has not been enough. India starts the twenty-first century with per capita income around half that of China and Indonesia, countries that in 1970 were at comparable stages of development. ${ }^{5}$ Not surprisingly, the National Development Council mandated a target of 8 percent per year in real GDP growth for the Tenth Plan (2002/03-2006/07); but the macroeconomic chapter of the Plan makes it clear that achieving this goal calls for a substantial cut in the fiscal deficit to raise public savings and investment. The second point is that interest payments are claiming a growing share of revenues, limiting government capital expenditure and spending on priority social programs. During the 2003/04 Union Budget discussions, the Finance Minister informed the Rajya Sabha that "Of our revenue, 50 percent is swallowed by payment of just interest on (government) debt. Another 20 percent goes on subsidies and 25 percent on defense. What am I left with?"6 In other words, the quality of the fiscal stance has deteriorated and options for adjustment are going to be constrained by the high level and non-discretionary nature of interest payments. Third, even though the high reserves offer insurance against a 1991-type crisis, this does not rule out a fiscal

\footnotetext{
${ }^{2}$ Ahluwalia (2002b), Williamson and Zagha (2002).

${ }^{3}$ Srinivasan (2001).

${ }^{4}$ Acharya (2001, 2002a, 2002b).

${ }^{5}$ World Bank (2003), Figure 1.

${ }^{6}$ Times News Network, Times of India, New Delhi, March 14, 2003.
} 
crisis itself. India is not immune to a Sargent-Wallace (1981) outcome, where rising interest payments compel the government to resort to inflationary finance, damaging macroeconomic credibility and raising real interest rates. If the high reserves are used to preserve exchange rate stability, that country could have a situation of appreciating real exchange rates and high real interest rates, hurting the real sector and lowering growth prospects. Thus at a minimum, failure to address the fiscal imbalance will hurt growth prospects and set poverty alleviation back.

An alternative viewpoint argues that with excess capacity in industry and record levels of reserves and food stocks, this is the right time for a fiscal expansion to stimulate growth. ${ }^{7}$ As is shown below, the two main arguments against this reasoning are first, that government debt and interest payments have already reached extremely high levels, constraining counter-cyclical fiscal policy. Second, the build up in reserves has not been a fortuitous accident but driven by a macroeconomic policy mix designed to keep inflation low and minimize external vulnerability in spite of the fiscal deterioration.

The need for "fiscal adjustment now" arises not because a crisis is imminent but because postponing reform is likely to result in an unmanageable debt and interest burden by the end of the Tenth Plan period notwithstanding the current low interest rates and burgeoning reserves. In contrast, a phased adjustment beginning now and focusing on a relatively small set of reforms is likely to yield substantial, positive benefits over the same horizon and be more conducive to longrun growth and poverty reduction. By "adjustment" is not meant an immediate, drastic cut in the fiscal deficit. The only way to do so given the extraordinarily high level of interest payments would be to cut capital expenditure even more, which would be undesirable. Instead, the advocated focus is on revenue mobilization and redirecting "non-merit subsidies" toward capital and development expenditure. The paper makes its case first by showing that a key factor in the fiscal deterioration during the Ninth Plan period (1997/98-2001/02) has been the significant reform-induced losses in revenue (both indirect tax revenue and financial-repression revenue), and also the government's inability to adjust public spending (as interest payments take up an increasing share of the budget). Debt dynamics worsened over 2002/03 despite the record lows in interest rates. The reason for this and the inadvisability of gambling on the persistence of low interest rates are spelled out. Second, it demonstrates that government debt dynamics are showing signs of being unsustainable. The primary deficit (non-interest fiscal deficit) is large and real interest rates have converged to growth rates. Third, the Reserve Bank of India's (RBI) policy of building up reserves and sterilizing them (to cushion against external shocks and keep inflation low, respectively), coupled with constraints on government spending (because of fiscal deficits and public debt) has resulted in low public and private investment, putting long-run growth in jeopardy relative to the levels needed for rapid poverty alleviation. Moreover, while higher reserves have increased liquidity, the joint balance sheet of the general government and the RBI has weakened. Fourth, projections show that postponing fiscal adjustment will push the debt burden to unmanageable levels by the end of the Tenth Plan period; but a phased adjustment that begins immediately will lower deficits and greatly improve spending composition.

Before proceeding, two points are worth noting. First, structural reforms to underpin faster growth are crucial to any fiscal reform scenario. These are not discussed here; World Bank (2003a) contains a detailed discussion. Second, the Government of India (GoI) and the RBI are cognizant of the need for a fiscal adjustment, as evidenced by numerous initiatives and policy pronouncements. The key is to find the momentum for implementation in the present environment of high reserves and low interest rates, a momentum this paper hopes to advance.

\footnotetext{
${ }^{7}$ Chandrasekhar (2000).
} 


\section{Macroeconomic Fundamentals}

\subsection{Public Finances and External Vulnerability}

Figure 1 depicts trends in the general government's (center plus states consolidated) gross fiscal deficit and debt as percentages of GDP in 1985/86-2002/03. It shows that the gross fiscal deficit averaged 9 percent of GDP before the crisis. It then fell sharply during the period of high growth and fiscal restraint that marked the Eighth Plan period (1992/93-1996/97), but resumed growing equally sharply after $1997 / 98$, returning to the 9-10 percent of GDP range during the Ninth Plan period (1997/98-2001/02).

\section{Figure 1: General Government Deficit and Debt Stock (\% GDP) 1985/86-2002/03}

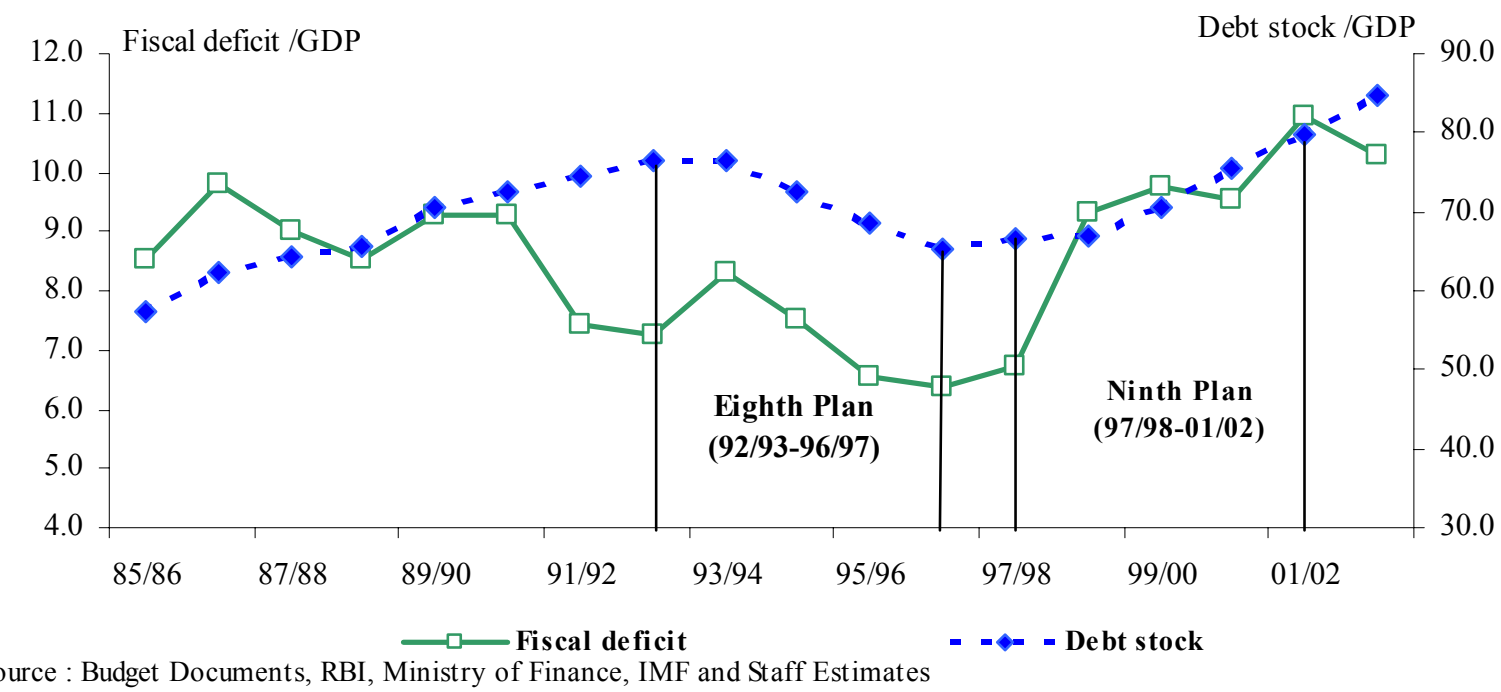

Figure 1 also shows that the ratio of general government debt rose from approximately 58 percent of GDP in $1985 / 86$ to 85 percent in 2002/03. ${ }^{8}$ This debt was the equivalent of $\$ 440$ billion with a rupee-to-foreign currency mix of 86:14 compared to 77:23 on the eve of the 1991 crisis. Debt of central public enterprises was another 10 percent of GDP, and guarantees by the center and states, the latter largely in support of borrowing by loss-making public enterprises in power and irrigation, amounted to 12 percent of GDP.

With fiscal deficit levels in the 10 percent of GDP range and government debt more than 25 percentage points of GDP higher than the mid-1980s, public finance fundamentals could be considered worse than in the pre-1991 crisis period. Table 1 shows trends in public finance and external vulnerability indicators. Data values over 1985/86-1989/90, the five years preceding the 1991 crisis, serve as a benchmark. The 1990s are divided into the period of rapid growth, 1992/93-96/97, which coincided with the Eighth Plan (shown in the table as $8^{\text {th }}$ Plan avg.); and the slowdown, 97/98-01/02, which coincided with the Ninth Plan period $\left(9^{\text {th }}\right.$ Plan avg.). ${ }^{9}$

\footnotetext{
${ }^{8}$ Throughout this paper, the component of general government debt denominated in foreign currency is valued at current exchange rates.

${ }^{9}$ This division of the time periods is used throughout the paper.
} 
The fiscal indicators shown in Table 1 depict a perceptible deterioration during the Ninth Plan period. Gross fiscal deficits returned to the levels of the mid-1980s after being cut sizably during the Eighth Plan period. Revenue deficits (current spending minus revenues, note that privatization proceeds are treated as financing, not as revenue) doubled from less than 3 percent of GDP in the second half of the 1980s to 6 percent during the Ninth Plan period. Primary deficits were reduced substantially during the Eighth Plan period relative to the second half of the 1980s; but then rose during the Ninth Plan period. Comparing the Ninth Plan period with the mid-1980s, the fact that the primary deficit was much smaller while the revenue deficit was much larger and the gross fiscal deficit about the same can only mean that rising interest payments displaced capital expenditure. General government debt fell from 71 percent of GDP at the end of 1989/90 to 65 percent at the end of the Eighth Plan period but then rose by 15 percentage points to the end of the Ninth Plan, and another five percentage points the following year.

Table 1: Key Macroeconomic Indicators

\begin{tabular}{|c|c|c|c|c|c|}
\hline $\begin{array}{c}\% \text { of GDP } \\
\text { (unless otherwise defined) }\end{array}$ & $\begin{array}{c}\text { Pre-crisis } \\
\text { period } \\
85 / 86-89 / 90 \\
\end{array}$ & $\begin{array}{l}\text { Crisis } \\
90 / 91 \\
\end{array}$ & $\begin{array}{c}\text { 8th Plan } \\
\text { avg. }\end{array}$ & $\begin{array}{l}\text { 9th Plan } \\
\text { avg. }\end{array}$ & $\begin{array}{c}02 / 03 \\
\mathrm{RE}\end{array}$ \\
\hline \multicolumn{6}{|l|}{ Fiscal and Debt } \\
\hline Gross fiscal deficit ${ }^{1 /}$ & 9.0 & 9.3 & 7.2 & 9.3 & 10.3 \\
\hline Revenue deficit ${ }^{1 /}$ & 2.8 & 4.0 & 3.6 & 6.1 & 6.8 \\
\hline Primary deficit ${ }^{1 /}$ & 5.3 & 4.8 & 2.1 & 3.5 & 3.7 \\
\hline Debt outstanding ${ }^{2 /}$ & 70.6 & 72.5 & 65.1 & 79.8 & 84.9 \\
\hline \multicolumn{6}{|l|}{ External Vulnerability } \\
\hline Forex reserves $\$ b^{2 /}$ & 4.0 & 5.8 & 26.4 & 54.0 & 75.4 \\
\hline M3/Forex Reserves $\%^{2 /}$ & 3694 & 2329 & 733 & 568 & 469 \\
\hline Short-term external $\mathrm{debt}^{3 /} /$ Forex reserves $\%{ }^{2 /}$ & 365 & 276 & 33 & 16 & 18 \\
\hline Current account balance & -2.2 & -3.1 & -1.2 & -0.7 & 1.0 \\
\hline Real GDP growth \% & 5.9 & 5.6 & 7.1 & 5.5 & 4.4 \\
\hline
\end{tabular}

Notes :

${ }^{1 /}$ For the general government. The figures for 2002/03 are revised estimates for central govt. and staff estimates for state governments.

${ }^{2 /}$ For end of last fiscal year in the period.

${ }^{3 /}$ External debt with original maturity less than a year plus all long-term debt falling due over the next one year.

Source: Government budget documents, Handbook of Statistics on Indian Economy and Annual Report 2001-02, Staff estimates

In contrast, external vulnerability indicators strengthened impressively. Foreign exchange reserves steadily built up after the 1991 crisis with a jump of $\$ 21$ billion in 2002/03, and now surpass $\$ 95$ billion. The table also shows two standard measures of international liquidity: broad money, or M3, divided by foreign exchange reserves; and short-term external debt divided by reserves. ${ }^{10,11}$ M3 was over 3,600 percent, and short-term external debt 365 percent of reserves the year before the BOP crisis. The first liquidity measure fell to less than 500 percent by March 31,2003 , and the second to a safe 18 percent. Both measures peaked at or around the time of the 1991 crisis and have fallen dramatically since. Their behavior explains why India is not on the verge of another BOP crisis in spite of the deterioration in the fiscal fundamentals.

\footnotetext{
${ }^{10} \mathrm{M} 3$ is defined as currency with the public, demand deposits with banks, other deposits with Reserve Bank of India, post office savings bank deposits and time deposits with banks.

${ }^{11}$ IMF (2000) identifies the ratio of short term external debt to reserves as a key indicator of vulnerability to an exchange crisis. Chang and Velasco (1998) identify international liquidity as a key factor in the East Asian crisis.
} 
The shift toward long-term domestic (rupee) debt in government financing after the 1991 crisis has also boosted liquidity. The weighted average maturity of debt issued through dated securities more than doubled from 6.6 years in $1997 / 98$ to 14.3 in 2001/02. ${ }^{12}$ Moreover, over 85 percent of central and state government securities are held by nationalized banks, The State Bank of India, the state-owned Life Insurance Corporation and RBI while the remainder is held by the mutual fund, Unit Trust of India, the National Bank for Agriculture and Rural Development (NABARD), employees provident fund and private banks. ${ }^{13}$ In short, much of the domesticallyissued debt is in the hands of government-owned or controlled entities.

\section{$2.2 \quad$ Fiscal Trends 1985/86-2001/02}

Table 2 shows that general government revenues fell considerably during the Ninth Plan period relative to the second half of the 1980s. ${ }^{14}$ Compared to the second half of the $1980 \mathrm{~s}$, capital expenditure fell by over three percentage points of GDP during the Ninth Plan period, while the sum of interest, administration and pensions rose by three percentage points of GDP and a 22 percentage points of revenue. Developmental spending on health and education stagnated, while that on irrigation, power and transport actually declined. Even the fiscal improvement secured during the Eighth Plan period involved a large compression of capital spending, as can be seen from the table. There was a hope that this compression would be offset by rising private investment in infrastructure; but with the exception of telecom, this has not happened on the desired scale. As noted in RBI (2003a), page III-46, a larger private role in infrastructure would require institutional reform and "economically efficient user charges to ensure the reasonable return on investment".

Table 2: General Government Fiscal Trends 1985/86-2001/02

\begin{tabular}{|c|c|c|c|c|}
\hline$\%$ of GDP & $85 / 86-89 / 90$ & $8^{\text {th }}$ Plan & $9^{\text {th }}$ Plan & $02 / 03$ \\
\hline (unless otherwise defined) & Avg. & Avg. & Avg. & Est. ${ }^{1 /}$ \\
\hline Revenue & 19.4 & 17.9 & 17.0 & 18.4 \\
\hline Current expenditure $^{2 /}$ & 22.1 & 21.5 & 23.1 & 25.3 \\
\hline Capital expenditure ${ }^{3 /}$ & 6.4 & 3.6 & 3.2 & 3.5 \\
\hline Gross fiscal deficit & 9.0 & 7.2 & 9.3 & 10.3 \\
\hline \multicolumn{5}{|l|}{ Memo } \\
\hline Interest & 3.8 & 5.1 & 5.8 & 6.5 \\
\hline Interest/Revenue & 19.4 & 28.5 & 34.0 & 35.1 \\
\hline Irrigation + power + transport & 4.7 & 3.5 & 3.5 & 3.8 \\
\hline Interest + admin. + pensions & 6.3 & 8.1 & 9.2 & 10.1 \\
\hline (Interest + admin.+ pensions $) /$ Revenue & 32.6 & 45.1 & 54.3 & 54.8 \\
\hline \multicolumn{5}{|c|}{$\begin{array}{l}\text { Notes: } \\
1 / \text { Revised estimates for the center and budget estimates for the states } \\
{ }^{2 /} \text { Refers to Revenue expenditure in the budget } \\
{ }^{3 /} \text { Refers to Capital outlay and net loans and advances from the center to the states }\end{array}$} \\
\hline
\end{tabular}

\footnotetext{
${ }^{12}$ RBI (2001a), Chapter XI Public Debt Management.

${ }^{13}$ RBI (2001b), Table 111.

${ }^{14}$ While 2002/03 shows a large revenue increase, it is based on the budget estimate for states, which tends to be optimistic.
} 
Table 3 presents more detail on the fiscal adjustment during the Eighth and Ninth Plan periods. ${ }^{15}$ The second column shows that, relative to the mid-1980s, the fall in revenues of 1.5 percentage points of GDP and the rise in interest payments of 1.3 percentage points was neutralized by a cut in capital expenditures of offsetting magnitude. The fall in revenues at a time of accelerating growth, especially of industry and manufacturing, the most tax-buoyant components of GDP, is attributable to the cuts in customs and excise duty rates undertaken as part of the reforms following the 1991 crisis. The object of these cuts was to increase efficiency in production and trade, with the fall in indirect taxes to be recouped by improvements in direct tax collections, although the latter has not so far occurred.

Table 3: Fiscal Adjustment Dynamics, 1985/86-2001/02 (based on period averages)

\begin{tabular}{l|cc}
\hline \multicolumn{1}{c|}{$\%$ of GDP } & $\begin{array}{c}8^{\text {th }} \text { Plan }(92 / 93-96 / 97) \\
\text { versus } \\
85 / 86-89 / 90\end{array}$ & $\begin{array}{c}9^{\text {th }} \text { Plan }(97 / 98-01 / 02) \\
\text { versus } \\
8^{\text {th }} \text { Plan }\end{array}$ \\
\hline Revenues & -1.5 & -0.9 \\
Primary deficit & -3.2 & +1.4 \\
Debt & +8.0 & +0.0 \\
Interest & +1.3 & +0.7 \\
Capital expenditure & -2.8 & -0.4 \\
Gross fiscal deficit & -1.8 & +2.1 \\
\hline
\end{tabular}

The rise in interest payments was due a rise in average debt/GDP levels and a rise in average interest rates. Controlling for the former, the rise in interest rates accounted for about 1 of the 1.3 percentage points increase in interest payments. We conservatively use 1 percentage point of GDP as an estimate of the loss of financial repression revenues as a result of introducing auctions for government securities in 1992/93, a general freeing up of deposit and lending rates and a large reduction in the cash reserve ratio and statutory liquidity ratio for banks. Financial repression has historically played an important role in India's public finances. Giovannini and de Melo (1993) estimate that revenues from financial repression averaged 2.86 percent of GDP per year for the years 1980-85. ${ }^{16}$ Using a similar methodology, Kletzer and Kohli (2001) estimate that financial repression revenues fell from an average of 6 percent of GDP over 1980-1990 to 2.9 percent over 1992-98. We do not intend to revisit these computations or address related methodological issues; based on the rise in interest payments during the Eighth Plan period, we suggest that easing financial repression "cost" the budget 1 percentage point of GDP. ${ }^{17}$ Thus, the simple story of fiscal adjustment during the Eighth Plan period is that revenues fell by about 2.5 percentage points of GDP as a result of tax reform and financial liberalization, and was compensated by cutting capital expenditure instead of finding alternative revenue sources as originally envisaged.

\footnotetext{
${ }^{15}$ We omit the crisis year, 1990/91, and the year following it.

${ }^{16}$ Computed as the ex post differential between foreign and rupee interest rates times the amount of government debt held outside the central bank. This calculation ignored the effect of tax concessions on government debt.

${ }^{17}$ The rise in interest rates during the Eighth Plan period might also reflect higher inflationary expectations following the devaluation of 1991; but only the liberalization of interest rates allowed this to be reflected in realized interest rates. Further, it would take a few years for the full effect to feed through, until all the historically issued debt matured.
} 
Table 3 also shows that the revenue decline continued and interest payments rose further during the Ninth Plan period, "compensated" by additional cuts in capital expenditure. Falling revenues account for 0.9 of the 1.4 percentage points of GDP rise in primary deficit relative to the Eighth Plan period. As capital expenditure endured a further cut of 0.4 percentage points, it follows that the rise in non-interest current spending in the form of higher salaries, pensions and administrative costs accounted for about 1 percentage point of GDP. This was probably driven by the Central Fifth Pay Commission award, the implementation of which began in 1997 at the center, followed the next year by the states.

Summarizing, we can say that relative to the pre-crisis mid 1980s, tax and financialrepression revenues fell by 2.5 percentage points of GDP during the 1990s as a result of needed reforms, offset by a compression in capital expenditure; ${ }^{18}$ while the Fifth Pay Commission award probably had a negative impact of about 1 percentage point of GDP. The impact of the latter is expected to attenuate over time, because of the discrete nature of civil service wage increases. Moreover, the issue is not so much that the civil service is over-staffed or the wage bill excessive when scaled by population and GDP respectively, but more that there is a skills imbalance, with most of the employment concentrated in low-skill jobs, which pay considerably more than comparable jobs in the private sector; with fewer and probably under-paid staff at the higher skills level needed for efficient social service delivery. ${ }^{19}$ Hence, reversing the fiscal slide needs to focus on mobilizing revenue and restoring government capital and development expenditure; cutting the wage bill is a secondary issue.

\subsection{Government Debt Dynamics}

The change over time in the general government debt-to-GDP ratio can be decomposed into two parts: the first attributable to the primary deficit/GDP ratio (pd); and the second, a term proportional to the difference between the real interest rate paid on government debt and the growth rate of real GDP, (r-g). During financial repression, we would expect the rise in debt to be less than the primary deficit (as ratios of GDP), because interest rates are kept artificially low; but with financial liberalization, interest rates would tend to rise and might eventually exceed growth rates, putting government debt on a much faster upward trajectory. We shall show that this is what happened during the Ninth Plan period.

Figure 2 presents the primary deficit and the term proportional to $(\mathrm{r}-\mathrm{g})$ based on the standard difference equation for government debt shown in Annex 2. It can be seen that after 1994/95, the term proportional to (r-g) becomes smaller in magnitude and over the last four years, has been either positive or close to zero, no longer offering the offset to the primary deficit that it did when financial repression was the norm.

\footnotetext{
${ }^{18}$ While revenues fell and interest payments rose further during the Ninth Plan period, it is impossible to say what part of this is cyclical and what part due to reforms, so the 2.5 percentage points should be treated as a lower bound.

${ }^{19}$ World Bank (2003) contains an analysis of the wage bill issue and the need for civil service reform.
} 
Figure 2 : Debt Dynamics

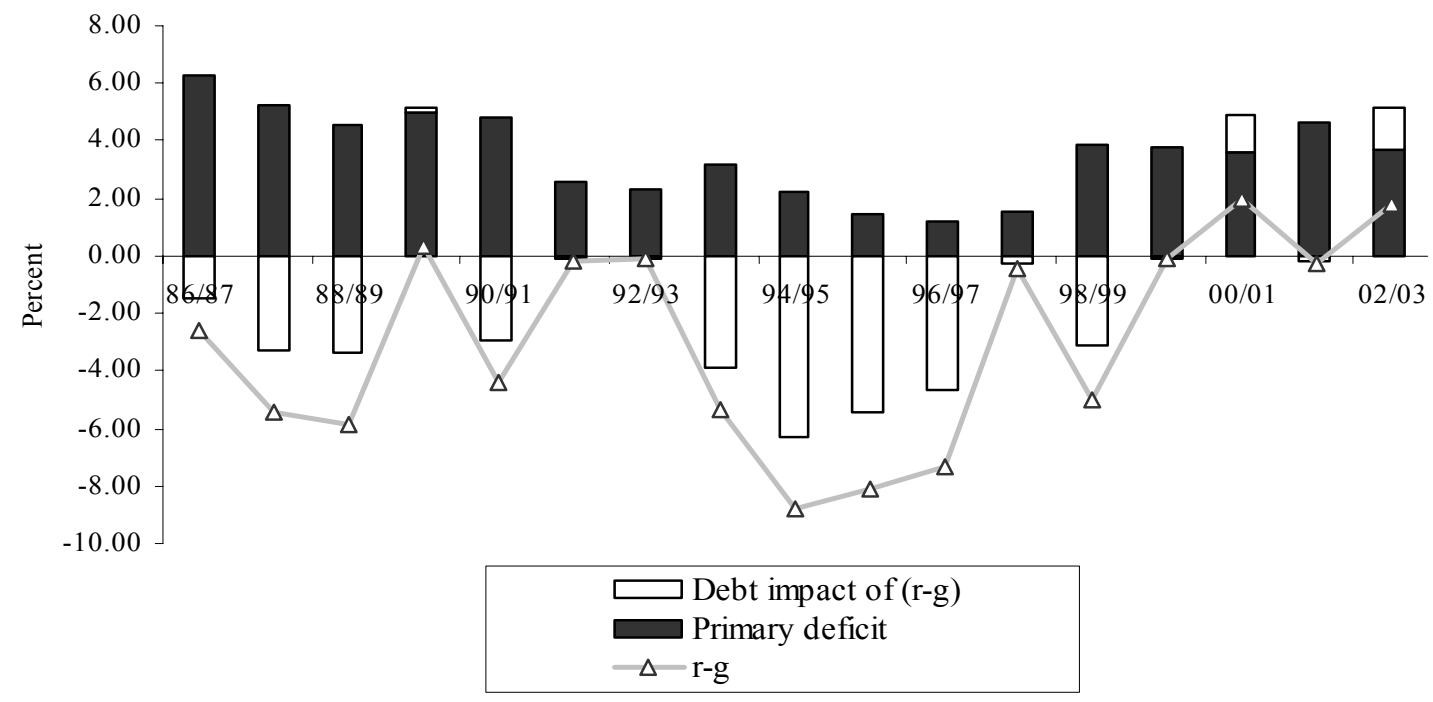

The implied value for $(\mathrm{r}-\mathrm{g})$ itself can be obtained through appropriate solution from the debt difference equation shown in Annex 2, and this is also plotted in Figure 2. ${ }^{20}$ Implied (r-g) has charted an upward trend after 1994/95 and has been either close to zero or positive since 1999/00, in spite of the record lows in interest rates over the last 18 months. On average, the implied real interest rate was a substantial 6 percentage points below the growth rate during the Eighth Plan period and explains why the ratio of general government debt to GDP (GGD/GDP) fell in spite of primary deficits averaging over 2 percent of GDP. But during the Ninth Plan period (i) the implied interest rate converged to or exceeded the growth rate, as anticipated in Serven (1996) and Reynolds (2001), while (ii) the primary deficit rose to an average of 3.5 percent of GDP. The combination of (i) and (ii) is by definition unsustainable without a fiscal correction, which, as argued in Box 1, is required in spite of the current low interest rates.

\footnotetext{
${ }^{20}$ Lahiri and Kannan (2002) directly calculate the interest rate as total interest payments divided by total debt, although strictly this should be augmented by a term capturing the exchange rate losses/gains on the external debt component of public debt. To do the latter accurately, one would need detailed information on the currency composition of public debt. We have calculated the effective rate of interest assuming that all external debt is dollar-denominated, and except for the years immediately before and after 1991, when the rupee depreciated significantly against the dollar, the implied interest rate tracks the directly calculated interest rate quite closely.
} 


\section{Box 1: Will Low Interest Rates Solve the Problem?}

Do the record lows in interest rates mean that the emphasis on unsustainable debt dynamics is misplaced? No, for the following reasons:

- Low interest rates stem not from better macroeconomic fundamentals but from weakness in the global economy and capital inflows. To the extent that capital flows into India have been driven by one-off events since September 11, 2001 including fears of increased scrutiny of accounts held overseas as part of anti-money laundering drives or by the instability in Iraq more recently, it would be risky to slow fiscal reform on a gamble that such flows will continue indefinitely. If capital flows subside and the global economy picks up, interest rates will once again be determined by medium-run inflationary expectations as molded by fiscal and macro fundamentals, which have weakened.

- Low interest rates for the government do not automatically mean low interest rates for the private sector, except for the best credits, as argued later in this paper.

- Low interest rates do not automatically improve debt dynamics. In fact, the increase in GGD/GDP has accelerated from less than 2 percentage points of GDP per year over the first three years of the Ninth Plan period (1997/98 to $1999 / 00)$ to over 4.5 percentage points of GDP per year over the last three years $(2000 / 01$ to 2002/03) notwithstanding the low interest rates. Why? First, primary deficits have gone up during the Ninth Plan period relative to the Eighth, increasing borrowing needs. Second, what matters is the difference between interest rates and growth rates. Slowing growth could offset the beneficial impact of lower interest rates. ${ }^{21}$ Third, what matters for debt dynamics is the average cost of GGD. Low interest rates at the margin obviously help, but will have to persist for sufficiently long (depending upon the inherited cost and maturity structure of the outstanding stock of GGD) to make a dent on the average rate. On the other hand, since the low interest rates have resulted from low global inflation, domestic inflation has also come down with India's increasing openness, which hurts to the extent that high nominal coupon debt has been issued in the past. ${ }^{22}$ The net effect is therefore ambiguous: low marginal interest rates help, low inflation hurts.

One "solution" that has been proposed is to engage in debt swaps in order to capitalize on the current low interest rates. However, these have to be carefully approached. To the extent that these are between the center and states, they will not affect the position of the general government unless the center can pre-pay the ultimate creditor without penalty; and to the extent that they are with banks, but not market-based (as for example in a scheme where the resulting capital gain is shared between banks and the government or fully captured by the government), they will weaken both the balance sheets of banks and erode their income with negative consequences down the road. But aligning small savings rates and provident fund (PF) returns with market indicators will lower the cost of new borrowings. ${ }^{23}$

Another option is to prepay external debt. The first two possibilities are to use divestment receipts or raise funds by borrowing in the domestic market to pay off external debt. The two are equivalent. If divestment receipts are used to prepay debt instead of financing the fiscal deficit then new borrowing would go up exactly by the amount of the divestment receipts. Thus, prepayment is equivalent to replacing an external liability with a domestic one; it does not change the balance sheet of the government. Interest payments will go down if the external debt carries a much higher interest rate (apart from posing exchange rate risk) than the new domestic borrowing. However, engaging in such prepayment also has its limits. Domestic financial institutions are already carrying some of the highest levels of government paper in the world relative to deposits and additional borrowing in the domestic market to pay off external debt means less funding for the private sector. The third possibility is to borrow from the RBI which then uses its reserves to pay off debt. This will improve the joint income position of the government and RBI (but not the joint balance sheet) if returns on reserves are lower than the rates paid on external debt. ${ }^{24}$ Thus, while debt swaps and prepayment may lower interest payments at the margin, a more fundamental fiscal adjustment is needed.

\footnotetext{
${ }^{21}$ But why doesn't growth pick up with lower interest rates? An answer is attempted below.

${ }^{22}$ Thus, RBI (2003a), page IV-20, notes that the average interest rate on new Central Government securities issued during the year reached a peak of 13.75 percent in 1995/96, declining gradually to 11.77 percent in $1999 / 00$ and 9.44 percent in 2001/02. Even these latter rates are "high" relative to today's inflation rates and growth.

${ }^{23}$ However, pre-paying debt now held by the NSSF that creates a wedge between its obligations and what it receives from the government will only create a contingent liability.

${ }^{24}$ It will also replenish RBI's holdings of government securities, which have been depleted by the sterilization of capital inflows. Of course to the extent this happens, it worsens the income position of RBI as foreign exchange reserves typically have lower returns than domestic government paper.
} 


\subsection{Quasi-Fiscal Issues}

In addition to the deterioration in "explicit" public finances, quasi-fiscal activities have become a growing threat since the mid-1990s. These may be grouped into three categories: losses associated with off-budget activities, notably, supply of irrigation and power; contingent liabilities, which may either be explicit, e.g., guarantees of bonds issued by loss-making public enterprises; or implicit, e.g., financial sector bailout costs resulting from implicit deposit insurance; and unfunded pension liabilities. These could be interrelated, e.g., the losses of State Electricity Boards (SEBs) may be financed by bonds issued with government guarantees.

SEB losses were estimated at Rs.332 billion in 2001/02, triple the level in 1996/97. ${ }^{25}$ To put this in perspective, the gross fiscal deficit of the states was 4.4 percent of GDP in 2001/02, or about Rs.1183 billion, a number which included only a portion of the power sector loss, namely, Rs. 83 billion. If the full amount of the loss were included, the fiscal deficits of the states would rise by an average of 30 percent. Some states have started reporting their deficits with and without the loss of the respective SEB in recognition of the growing problem.

If SEB losses are explicitly included in the general government deficit, these would increase by a significant 1.0-1.5 percentage points of GDP, i.e., the gross fiscal deficit would be 11.5 percent of GDP instead of 10 percent. Such inclusion appears to be only a matter of time the Ahluwalia Committee ${ }^{26}$ recommended replacing past-due arrears of SEBs to central government agencies by state government bonds, while the tripartite agreement signed in March 2003 by RBI, state governments and Ministry of Power allows RBI to use amounts due to the states to settle any unpaid bills presented to the respective SEB by central agencies.

Guarantees have risen sharply after 1996, mostly in connection with borrowings by SEBs and special purpose vehicles (SPVs) established for large irrigation projects. ${ }^{27}$ CRISIL estimates that of the market borrowings by state-level entities guaranteed between 1995-2002, Rs.440 billion will be called over the next five years. While this may not seem much, this estimate excludes guaranteed loans from banks/FIs such as NABARD, HUDCO, LIC, NCDC, REC, public sector banks and regional rural banks. Moreover, the guarantors themselves, i.e., the state governments, are already heavily indebted.

Financial sector bail-out costs have not so far been significant, unlike in East Asia and some of the transition countries of Central and Eastern Europe. Since 1992/93, relatively small amounts of money have been spent to assist nationalized banks, regional rural banks, UTI, IDBI and IFCI, with another 0.8 percent of 2002/03 GDP identified to help UTI, IFCI and IDBI . The banks' reported gross non-performing loans (NPLs) were 10.4 percent of loans as of March 2002; net of provisions the figure was 5.5 percent; and net non-performing loans as a percent of assets were 2.3 percent or about 1.5 percent of GDP. While some financial analysts have suggested that NPLs are substantially understated by various "evergreening" methods, a doubling of the gross figure would put NPLs at less than 7 percent of bank assets, or about 4.5 percent of GDP. Another indicator of risk, lending for stocks, real estate, and commodities, is less than 4 percent of lending. While off-balance sheet operations are equal to nearly 60 percent of the balance sheet, three-fourths are forward exchange contracts (half by the foreign banks) mostly related to

\footnotetext{
${ }^{25}$ Source: Planning Commission, Government of India: Annual Report (2001-02) on the Working of State Electricity Boards \& Electricity Departments, May, 2002. The actual financial loss is even greater because of collection problems.

${ }^{26}$ Report of the Expert Group, Settlement of SEB Dues, May 2001.

${ }^{27}$ CRISIL (2002).
} 
exports and imports and often with RBI as the counter-party. ${ }^{28}$ While these numbers are low in comparison with East Asia and China, this has to be looked at in the context of public sector debt that is over 90 percent of GDP in an environment of worsening government debt dynamics.

Pension liabilities have been growing rapidly both at the center and states. At the center, pension spending for civil servants grew by more than 20 percent per year during the 1990 s, and has now reached 1 percent of GDP. The situation is even more difficult at the state level. For example, in Uttar Pradesh ${ }^{29}$, the ratio of pension spending to state GDP increased from 0.4 percent to 1.2 percent during the 1990s. The White Paper on Tamilnadu Government's Finances issued in 2001 (pages 19-20) notes that pension commitments "have been growing at an incredible rate of 30 percent per annum on an average during the last five years and constitute the fastest growing component of the total revenue expenditure of the State Government". Pensions as a percentage of revenue expenditure grew from 5 percent in 1991/92 to 13 percent in 2000/01. Pension expenditures at the central and state levels are likely to keep on growing at a fast pace, especially at the state level where employment more than doubled over the past 30 years. Preliminary estimates conducted in 2001 using the World Bank PROST actuarial model suggest that the present value of central and state pension liabilities could amount to 25 percent of GDP. ${ }^{30}$

\section{Crisis Proofing}

In spite of the rise in the level of government debt and the deterioration in its dynamics, India is not on the verge of a macroeconomic crisis such as that endured recently by Russia, Turkey and Argentina, which apparently exhibited better fiscal fundamentals on the eve of their crises than India has over the past few years. ${ }^{31}$ There are several reasons for this. First, there is only limited capital account convertibility. Second, cross-country comparisons are complicated by differences in the currency composition of debt, its maturity, whether or not the real exchange rate is in equilibrium and the size of contingent liabilities and potential balance sheet currency/maturity mismatches in the banking and corporate sectors. In India, there has been a shift towards long-term rupee debt in financing the fiscal deficit after 1991, while strictures on external borrowing by corporates and banks automatically lower the potential for currency mismatches. Third, in contrast to the recent crisis countries, India has an impeccable credit history (no defaults, no debt restructurings) and a track record of low inflation and high macroeconomic stability, which permits it to issue long-term debt denominated in its own currency, an option unavailable to countries such as Russia, Turkey and Argentina. ${ }^{32}$ Fourth, countries with unsustainable public debt dynamics which eventually experienced crisis, such as Russia and Argentina, simultaneously had low international liquidity. This combination proved intractable, even with substantial bailout packages. In contrast, India's international liquidity has improved substantially after 1991 as noted above.

After the crisis, there was a conscious decision to build up reserves to "provide greater insurance against external sector stresses and uncertainties". ${ }^{33}$ Acharya (2001, page 17) notes that "the capital account surplus reached its peak in 1993/94 (at 3.5 percent of GDP) and has been well below that level in subsequent years. Nevertheless, except for 1995/96, the capital account has been large enough in relation to the corresponding current account deficit in each of the last ten years (i.e., 1991/92-2000/01), to ensure accretion to foreign exchange reserves."

\footnotetext{
${ }^{28}$ While not a serious issue at present, this could potentially encumber RBI reserves and bears monitoring.

${ }^{29}$ See Zahir (2002)

${ }^{30}$ A detailed analysis of the pension liability is beyond the scope of this paper, although we flag it as an important unfunded liability. See also World Bank (2003a).

${ }^{31}$ For the comparison of fundamentals, see IMF (2002), chapter III, page 37, and Ahluwalia (2002a).

32 These factors, together with the degree of dollarization have been stressed as critical factors in determining default risk in Rogoff, Reinhart and Savastano (2003).

${ }^{33}$ Acharya (2001), page 16.
} 
Reddy (2002, page 1913) notes that “....two factors are responsible for significant addition to reserves in the recent past viz, a far lower level of current account deficit (CAD) than the expected sustainable level of about 2 percent of Gross Domestic product (GDP) each year and a continued inflow of capital...".

Table 4 confirms that the reserve increase was driven by the fall in the current account deficit after the 1991 crisis; the surplus on the capital account is more or less constant except for a small, apparently temporary increase during the Eighth Plan period. It divides the post-crisis reserve accumulation into three phases. The first is the Eighth Plan period, during which fiscal and current account deficits fell, while private investment rose from a rate of 13 percent of GDP during the second half of the 1980s to over 15 percent. The second is the Ninth Plan period, when fiscal deficits jumped upward, but the current account deficit fell further and reserve accumulation accelerated. Private investment rose slightly. The third phase is post-April 2002, when reserves have boomed and a small current account surplus has appeared.

Table 4: Stages in Reserve Accumulation

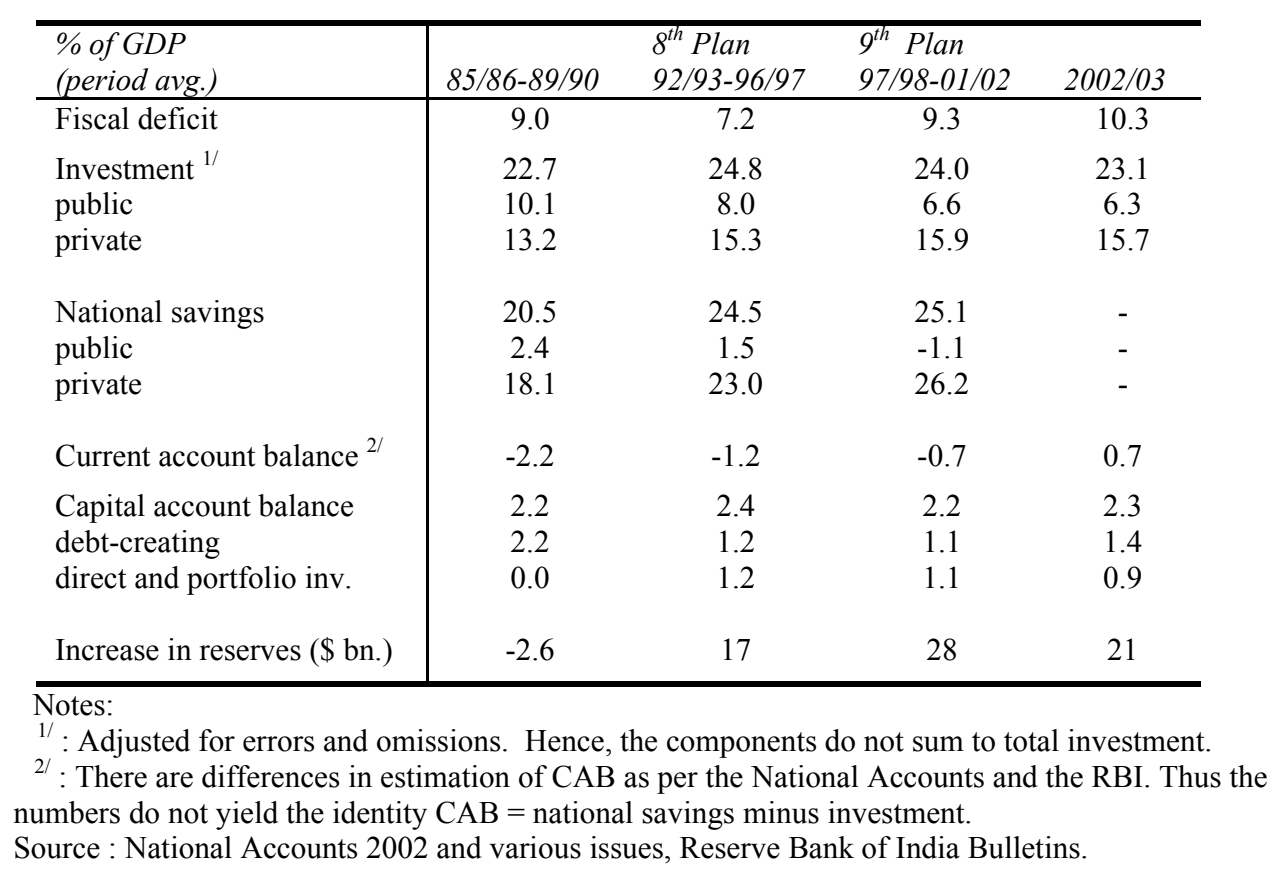

The fact that private investment grew by much less than private saving during the Ninth Plan relative to the Eighth has been used to argue that the rising fiscal deficit absorbed part of the increase in private savings and to this extent crowded out private investment, thereby helping to keep the current account deficit in check. ${ }^{34}$ We return to this point later in the paper.

The acceleration in reserve accumulation during 2002/03 and after raises two questions: (i) what is driving it? and (ii) how to manage the macroeconomic consequences. About 40 percent of the reserve increase during 2002/03 happened after November 2002. An unknown part of this might have been driven by capital inflows related to fears of the Iraq war, and therefore, this pace of accretion might not be maintained. ${ }^{35}$ Another possibility is we are seeing capital

\footnotetext{
${ }^{34}$ Ahluwalia (2002), Acharya (2001) and IMF (2002).

${ }^{35}$ See RBI (2003b) and Kapur and Patel (2003). Reddy (2002) contains a comprehensive account of foreign exchange reserves policy through the 1990 s.
} 
reflows from overseas as a result of the instability in the Middle East and money attracted by the rupee-dollar interest differential given expectations about the exchange rate. Whatever the reason, we show next that the reserve build-up has improved liquidity, but not solvency.

The high reserves have not strengthened the joint balance sheet of the general government and RBI because the RBI has been sterilizing the capital inflows to keep inflation low. Let $\delta$ denote the consolidated liabilities of the general government and RBI, which we call net public debt, $d$ general government debt, $f$ RBI's net foreign assets and $c$ its net domestic assets, all expressed as ratios to GDP. By definition, $\delta$ is given by: ${ }^{36}$

(1) $\delta_{t}=d_{t}-f_{t}-c_{t}$,

where $\mathrm{t}$ denotes time. Now consider a situation where increases in reserves are sterilized by RBI sales of government securities, i.e., reductions in its net domestic assets, $c$, so that $\Delta f=-\Delta c$. $^{37}$ It then follows from (1) that:

(2) $\Delta \delta=\Delta d$,

i.e., the trajectory of net public debt and general government debt should be expected to be the same. In other words, while growing foreign exchange reserves boost international liquidity, they do not strengthen the combined balance sheet of the government and RBI. Essentially, domestic debt is being issued to finance the deficit and buy reserves. ${ }^{38}$ Table 5 brings this out clearly. We see that net public debt increased by 23 percentage points of GDP between 1996/97 and 2002/03; from Table 1, general government debt increased by 20 percentage points of GDP over the same period. We also see that between 1997/98 and 2001/02, the sum of net foreign assets and net domestic assets ("base money") fluctuated in a small range of about 13.5-14 percent of GDP, but fell sharply in 2002/03. This is consistent with a policy of sterilization to keep inflation low, with the fall in base money in 2002/03 attributable to the appreciation of the rupee. ${ }^{39}$

Table 5 : Net Public Debt (End March)

\begin{tabular}{lrrrrrrrr}
\hline & $90 / 91$ & $96 / 97$ & $97 / 98$ & $98 / 99$ & $99 / 00$ & $00 / 01$ & $01 / 02$ & $02 / 03$ \\
& Crisis & & & & & & \\
\hline General govt debt (Rs. billion) & 4121 & 8913 & 10127 & 11655 & 13669 & 15862 & 18323 & 20810 \\
(-) Net foreign exchange assets of RBI & 80 & 948 & 1159 & 1380 & 1659 & 1972 & 2640 & 3582 \\
(-) Net domestic assets of RBI & 682 & 952 & 1001 & 1042 & 933 & 878 & 569 & -529 \\
(+) Net non-monetary liabilities of RBI & 270 & 352 & 433 & 605 & 702 & 793 & 1012 & 1265 \\
Net public debt & 3630 & 7364 & 8400 & 9839 & 11779 & 13806 & 16127 & 19022 \\
\hline Memo : \% GDP & & & & & & & & \\
Net foreign exchange assets of RBI & 1.4 & 6.9 & 7.6 & 7.9 & 8.6 & 9.4 & 11.5 & 14.6 \\
Net domestic assets of RBI & 12.0 & 7.0 & 6.6 & 6.0 & 4.8 & 4.2 & 2.5 & -2.2 \\
Net public debt & 63.8 & 53.8 & 55.2 & 56.5 & 60.8 & 65.6 & 70.2 & 77.6 \\
\hline
\end{tabular}

Source: Reserve Bank of India, Monthly Bulletins

\footnotetext{
${ }^{36}$ The definition of net public debt also includes some other terms on RBI's balance sheet, as shown in Table 5, which we ignore here for simplicity.

${ }^{37}$ Strictly speaking, this holds approximately because net foreign assets and net domestic assets are both expressed as shares of GDP.

${ }^{38}$ Another way of making this point is to say that genuine assets can be created only by saving, not borrowing. To quote Flood and Jeanne (2000) "...reserves are expensive window dressing...by accumulating them the government behaves as an insolvent household that would try to impress creditors by financing large cash balances with credit card debt".

${ }^{39}$ That is, RBI was exchanging an appreciating asset (rupee government securities) for a depreciating one (dollars) with a lower nominal coupon. For an analysis of sterilization and its effects, see Lal, Bery and Pant (2003).
} 


\section{Macro Policy and Growth}

The policy of accumulating reserves while keeping inflation low in the face of rapidly deteriorating public finances suggests that India has had its own macroeconomic policy trilemma after $1997 / 98$, seemingly opting to choose the first two out of the following three objectives: ${ }^{40}$

1. Keep inflation at single-digit levels

2. Minimize vulnerability to external crisis by accumulating reserves

3. Maximize long-run growth and poverty reduction.

Objectives 1 and 2 seem to have been pursued at the expense of 3 . Given the positive link between growth and income poverty reduction in India (World Bank 2003), a reconfiguration of fiscal policies that promotes growth would speed poverty reduction while also improving debt dynamics. We pursue the fiscal policy-growth link by asking two questions: will India grow out of its debt problem, or does it need a fiscal adjustment to achieve satisfactory growth in the first place? And what has been the impact of macro policy on private investment? To anticipate a later section, we also note that unlike the trilemma in Obstfeld and Taylor (1998), the above is not a true trilemma, in that a fiscal adjustment which reduced deficits and improved the composition of government spending would permit all three objectives to be attained.

\subsection{A Growth Crisis?}

It was argued above that notwithstanding the record lows in interest rates, a fiscal correction would be needed to place government debt on a sustainable path. The Tenth Plan document sheds more light on this topic. Chapter 2 of the plan document notes that in order to meet the growth target of 8 percent per year the investment rate will need to rise by 4 percentage points to a little over to 28 percent, with the increment in domestic savings contributing 3.5 percentage points and the rise in the current account deficit (CAD) the balance of 0.5 percentage points. The ICOR is assumed to fall from 4.5 to 3.6, investments to grow at 14 percent per annum compared to the long-run growth rate of 6.5 percent, and consumption by 6.9 percent per annum. The chapter notes that private household savings rose over the Eighth and Ninth plans in response to the cut in tax rates and consequent rise in disposable income. This could slow down in the Tenth plan period because of the need to raise the tax/GDP ratio, and highlights the need to increase public savings from -1.7 percent in the base year of the Tenth plan (2001/02) to +2.1 percent in its last year (2006/07). Unless this happens, the plan document is quite specific that the growth target is unlikely to be reached. It also cautions that the CAD should not be used to slacken the public savings target, and that a safe upper limit is 3 percent of GDP.

The plan document then compares the fiscal deficits projected under the above savingsinvestment scenario (the "desirable deficit" from the perspective of attaining a compound average growth rate of 8 percent during the Tenth Plan period) with the fiscal deficit that would achieve sustainability, defined as a stabilization of the government debt/GDP ratio at the base year (2001/02) level. The comparison is summarized in Table 6.

\footnotetext{
${ }^{40}$ The trilemma in Obstfeld and Taylor (1998) notes that only two out of the following three goals can be selected for an open economy: (i) use exchange rate as an instrument for price stability; (ii) keep capital account open for efficiency and flexibility; and (iii) pursue an activist monetary (interest rate) policy.
} 
Table 6: Sustainable and Desirable Deficits In The 10th Plan Context

\begin{tabular}{|c|c|c|c|c|}
\hline & \multicolumn{2}{|c|}{$\begin{array}{c}\text { Sustainable Deficit }{ }^{1 /} \\
\text { (1) }\end{array}$} & \multirow[t]{2}{*}{$\begin{array}{c}\text { Desirable Deficit }{ }^{2 l} \\
\text { (2) }\end{array}$} & \multirow[t]{2}{*}{$\begin{array}{c}\text { Base year } \\
\text { (3) }\end{array}$} \\
\hline & $g=6.5$ & $g=8.0$ & & \\
\hline Combined & 7.4 & 8.6 & 6.8 & 9.3 \\
\hline Center & 4.4 & 5.2 & 3.6 & 4.9 \\
\hline States & 3.0 & 3.4 & 3.2 & 4.5 \\
\hline \multicolumn{5}{|c|}{ Notes: ${ }^{1 /}$ Table 2.21 of Tenth Plan } \\
\hline \multicolumn{5}{|c|}{${ }^{2 /}$ Table 2.22 of Tenth Plan } \\
\hline \multicolumn{5}{|c|}{ Source: Tenth Five Year Plan, Gol } \\
\hline
\end{tabular}

Comparing columns (1) and (3) indicates the sizable fiscal correction needed at the level of the states to achieve sustainability even if the assumed growth of 8 percent were to materialize. Comparing columns (2) and (3) shows that an even bigger fiscal correction is needed to generate the needed public savings for investment compatible with 8 percent growth in the first place. It follows that a fiscal adjustment is needed to generate the investment needed for growth which will then lead to debt sustainability: India is not going to grow out of its debt problem without a fiscal adjustment.

\subsection{Impact on Private Investment}

Notwithstanding the boom in private investment after the 1991 crisis and the pick up in growth during the Eighth Plan period, growth slowed to 5.8 percent over 1997-98 to 2000-01. ${ }^{41}$ Overall, growth in the 1990s was similar to that in the 1980s, the attainment of a trend rate of growth of about 6 percent. What will push the trend rate of growth to 8 percent? The Tenth Plan document notes that more public saving and investment and hence a fiscal adjustment are part of the answer, because of the direct benefits (more infrastructure) and the spin-offs (banks having more incentive to lend to the private sector, a less uncertain macroeconomic environment). Structural reforms will also help, especially addressing impediments such as small-scale industry reservations and labor regulations. ${ }^{42}$ Similarly, creating a more conducive environment for private investment will also be helpful in the more competitive environment in which Indian firms find themselves today.

In this context, one must ask if private investment has been crowded out by the macro policy stance. ${ }^{43}$ This is difficult to prove conclusively because the rise in the private savingsinvestment gap noted above (Table 4) may also have come about as the result of a needed period of consolidation following the private investment boom during the Eighth Plan period. But there is substantial evidence to suggest that the macro policy stance has not been the most conducive to promoting private investment.

\footnotetext{
${ }^{41}$ There is some controversy about how much even of this lower growth was artificially boosted by the Fifth Pay Commission (FPC) Award. Acharya (2001) contends that suitably adjusting real value-added in the category "Public Administration and Defence" would lower growth to 5.4 percent. RBI (2003a) finds a minimal impact of the FPC award.

${ }^{42}$ For a detailed discussion of structural reform issues, see World Bank (2003a).

43 World Bank (2000) and Reynolds (2001) document a negative association between fiscal deficits and private investment, although establishing causality from high deficits to low private investment is a different matter.
} 
First, the crowding out of government investment by rising revenue deficits potentially hurts private investment. For example, an empirical study in RBI (2002c) concludes that public investment in infrastructure has strong positive complementarities with private investment.

Second, the desire to build up reserves while sterilizing capital inflows to keep inflation low means higher real interest rates the higher the fiscal deficit and government debt, especially in an economy with capital controls. In fact, real interest rates for borrowers rose with growing government debt and remained high between 1996/97 and 2001/02, averaging over 12 percent per annum as shown in Figure 3 based on Table 1 in Mohan (2003). Thus, it does appear that a "loose fiscal-tight money" policy mix emerged during the Ninth Plan period to help meet reserve and inflation targets in the absence of a fiscal adjustment.

Figure 3 : Real Interest Rates (1990/91-2001/02)

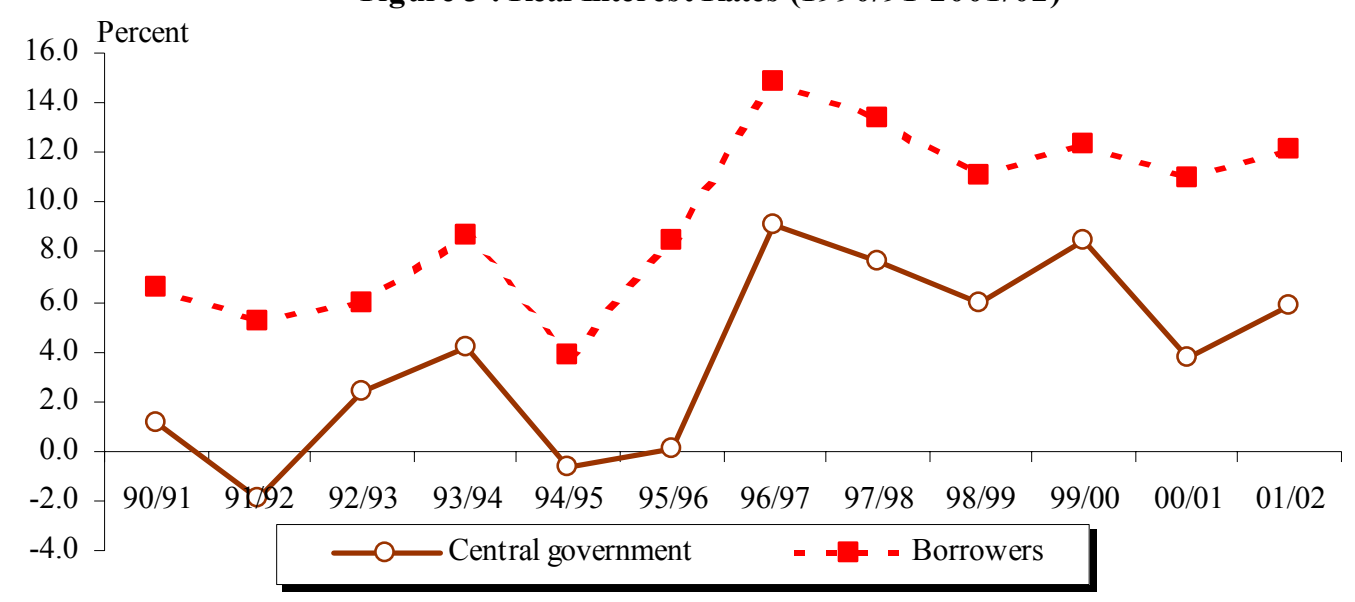

Source: Speech by Rakesh Mohan, RBI Monthly Bulletin (Jan 2003)

Third, over the last two years or so, interest rates have fallen in India in line with global trends; but there are significant barriers to translating the low marginal interest rates on government debt into low lending rates to the real sector. The Indian financial system is segmented and must conform to various minimum lending and portfolio composition requirements. For example, the prime lending rate tends to be kept high because it cannot be exceeded when lending to the priority small scale sector, which might partly be motivated by the inefficient policy of small-scale reservations. Insurance companies must hold at least 50 percent of their assets in government debt and provident funds at least 50 percent in central government debt and 25 percent in state government debt. Provident funds have also purchased debt of "special purpose vehicles" (SPVs) guaranteed by the state governments. Annual inflows into small (postal) savings, which compete with banks for deposits, are invested wholly in government debt. These have grown from an average of 7.9 percent of GDP in the Eighth Plan to nearly 10 percent currently and consume nearly the whole increase in net household financial saving. The administratively-determined interest rates for these instruments were set artificially high, at 10.513 percent until 2000 and are still 7.5-9 percent, with tax concessions. This worsens public debt dynamics while raising the cost of funds for banks and hence lending rates to the private sector. Moreover, banks are under pressure to reduce their non-performing assets, which attracts them even more toward holding government debt. And non-bank financial corporations ${ }^{44}$ (NBFCs),

\footnotetext{
${ }^{44}$ See Bossone and Zahir (1999)
} 
which held little government debt and funded riskier firms, represented an average of 7.7 percent of GDP during the Eighth Plan period but only 1.1 percent during the Ninth. Their decline probably contributed to the rapid growth in bank deposits after 1996. Therefore dominant government ownership of the financial sector, the portfolio problems of banks, the investment rules for insurance and PFs, and interest rates on small savings all create a natural proclivity towards lending to the government. This is reinforced by the incentive structure in banks, whereby managers complain of being subject to criminal investigation if a loan to a private enterprise goes sour. All this could prevent low interest rates for the government from automatically translating into low rates for the private sector, except for the best credits ${ }^{45}$.

Fourth, recent work presented in Aizenman (2003) suggests that unless fiscal reforms are introduced to compensate for the loss of implicit revenues from financial repression, financial reforms may not yield the intended benefits in terms of more efficient resource allocation. ${ }^{46}$ Instead, a growing proportion of bank assets may be invested in government debt. As of March 2002, about 28 percent of bank assets were invested in government debt and another 5.6 percent was with the RBI. Indian banks have one of the highest ratios of government debt to deposits in the world, similar to Latin American countries and much higher than most East Asian comparators, even after the crisis. A fiscal adjustment would clearly give banks more incentive to lend to the private sector.

\section{Fiscal Reform Priorities}

Based on the preceding analysis, the two priorities are to complete tax reform in order to mobilize more revenue; and improve the composition of general government expenditure. Neither will be easy or quick.

Chapter 2 of the Tenth Plan document sets a goal of raising central government gross tax revenue from 8.6 percent in 2001/02 to 10.3 percent of GDP by the end of the Tenth Plan, essentially returning to the level of 1991/92. Plan projections assume an increase in tax buoyancy from 0.8 during the Ninth Plan to 1.26 during the Tenth. Most of this is expected to come from indirect taxes, customs duty in particular. Achieving this goal assumes a withdrawal of import tariff exemptions (except on strategic imports); a strong resumption of manufacturing sector growth, as this sector has the highest tax buoyancy; and extending the tax net to include the booming services sector. The states' own tax collection is projected to rise from 5.9 percent of GDP in the base year to 6.6 percent by the end of the Tenth Plan; this crucially rests on the implementation of a unified VAT covering all goods and services. In like vein, the Kelkar Committee reports ${ }^{47}$ emphasize the completion of tax reform by eliminating exemptions, the bringing into the tax net of services and agriculture and improved information technology-based tax administration. Although tax administration was given due prominence in the Union Budget for 2003/04, there has been a tendency to increase exemptions and special rates, even in excise despite the rationalization of main rates; and there has been no move to tax agricultural income, which will perpetuate incentives to disguise non-agricultural income as agricultural income.

Given the fiscal constraints identified above, one way to increase capital and developmental expenditure is to re-direct spending away from subsidies. These have three main components: (i) food and fertilizer subsidies, which amounted to a total of $1.4 \%$ of GDP in

\footnotetext{
${ }^{45}$ See Hanson (2002).

${ }^{46}$ Aizenman's (2003) argument is that financial reforms may be forced by greater trade integration because the latter enables domestic residents to escape financial repression through capital flight facilitated by export and import underand over-invoicing. This makes financial repression more costly as a tax and therefore leads to financial reform; but fiscal reforms are needed to compensate for the implicit revenue loss. Patnaik and Vasudevan (no date) discuss capital flight from India through trade misinvoicing during the 1990s.

${ }^{47}$ Report of the Task Force on Direct Taxes, Report of the Task Force on Indirect Taxes, MOF, December 2002.
} 
2002/03; (ii) a petroleum subsidy of 0.4 percent of GDP; and (iii) a power subsidy of 1.5 percent of GDP of which about 0.5 percent is explicitly included in state government budgets and the balance is an implicit subsidy.

Foodgrain and input subsidies have distorted farmer cropping and investment decisions and thereby contributed to natural resource degradation (soil nutrient imbalances, water logging, salinity, etc.). At the same time, public investments in agriculture over the last decade have declined in large part because of the need to finance subsidies in the foodgrain, fertilizer, irrigation, and power sectors. Therefore, a shift in central expenditures from food (subject to the maintenance of a minimum social safety net) and fertilizer subsidies towards productivityenhancing investments, including irrigation, rural infrastructure, and research and extension, would give the agricultural sector and off-farm employment a much-needed boost. ${ }^{48}$

The petroleum subsidy is to be phased out over the medium term. The power subsidy is much more difficult politically, even though it is regressive and the poor benefit little from subsidized electricity. ${ }^{49}$ Tariffs covered only $68 \%$ of the cost of supply in $2001 / 02$. At the same time, there is high dispersion in tariffs, with commercial and industrial users cross-subsidizing agricultural and domestic consumers and being charged rates far in excess of the cost of supply. As a result of this and the poor quality of supply, many manufacturing companies install their own generators.

The financial and social case for power sector reform is clear, as are the essential elements. Average tariffs need to be raised to reflect cost of supply; universal metering of consumption is required, especially for agricultural and domestic consumers; payments discipline needs to be enforced; and a targeted subsidy scheme needs to be introduced for poor households and farmers so that the cross-subsidy burden on industrial and commercial users can be eliminated. GoI has recently initiated a few potentially decisive steps to give states stronger reform incentives. ${ }^{50}$ For these to work, privatization of distribution, stronger action on tariffs, governance improvement and financial restructuring are needed.

On guarantees, there are two issues: what to do about the existing stock; and how to minimize or stop the new flow altogether. On the first, one idea is to create a guarantee redemption fund, ${ }^{51}$ though the question is how this will be funded given fiscal constraints. Besides, it will work only in conjunction with a correction of the fundamental problems in power and irrigation - especially tariff setting - which is also needed to stop the flow of new guarantees which would otherwise be needed for fresh borrowings to finance continued losses.

An important spin-off from fiscal reform will be to enhance the role of the financial sector in efficient resource allocation ${ }^{52}$ and thereby reap the benefits associated with a more liberalized financial system. Another challenge is to minimize financial sector risks and thereby the build up of contingent fiscal liabilities. In this connection, the new Securitisation and Reconstruction of Financial Assets and Enforcement of Security Interest Bill (2002), which allows banks to take over collateral more easily, could push debtors to pay up. Similarly, establishment of Credit Information Bureaus should help in sharing information on credit risk, which would lower transactions costs while also helping to control NPLs. It would particularly

\footnotetext{
${ }^{48}$ Deininger and Deininger (2001) and the forthcoming paper on 'Targeted Public Distribution System: Is it Reaching the Poor?"

${ }^{49}$ World Bank (2001b) and (2002b).

${ }^{50}$ Parliament passed a new Electricity Act in 2003 and the Ministry of Finance launched the Accelerated Power

Development and Reform Program. For more details, see World Bank (2003a).

${ }^{51}$ RBI (2003e)

${ }^{52}$ See for example the analysis in Bossone, Mahajan and Zahir (2003) which explores through a choice theoretic model how changes in financial infrastructure affect the investors' resource allocation decisions and also tests empirically the hypothesis with cross-country regressions.
} 
help with SMEs, which at present suffer from very high real lending rates owing to the perception of high risk, as noted in Mohan (2003). One topic that is relevant at present is interest rate risk. Financial institutions which have invested in long-term government paper have been making large trading profits as interest rates continued to fall, but now face risks from the possibility of rising interest rates. In an attempt to counteract this, RBI has issued a directive on creating an Investment Fluctuation Reserve. While banking regulation has improved, some of this has been offset by easing regulations to encourage restructurings and lending for housing and infrastructure, which is beset by a weak framework for user charges.

Insurance and provident funds are heavily invested in government debt, and will face losses as interest rates rise. Moreover, state provident funds have also invested in special purpose vehicles (SPVs) guaranteed by the state. Many of these assets are no longer earning interest, making the performance of the state provident funds even more dependent on debt servicing by cash starved States, now that the guarantees are beginning to be called. The ability of these provident funds to meet their obligations is likely to affect public confidence in government debt issues more broadly. Finally, the administratively set returns on the provident funds are significantly above market rates, which encourage the management to engage in risky investments in the non-regulated portion of their portfolio and, more generally, create a potential contingent liability for the central and state governments along the lines of UTI. Linking rates on the provident fund more closely to the market, and reducing the role of administratively fixed rates, would help control the continued build-up of these problems. A similar link to rates on small savings would save interest costs for states.

A last point is on institutions for fiscal management. The Fiscal Responsibility and Budget Management Act passed by the Parliament in 2003 mandates the central government to eliminate its revenue deficit by March 31, 2008. A few states ${ }^{53}$ have passed similar acts and others are in the process of formulating these. In addition to revenue mobilization and subsidy reform, making this mandate credible would require strengthening the institutional framework, such as reforming the borrowing regime for states, expanding the volume of center-to-state transfers linked to reform and performance (such as the Fiscal Reforms Facility and the Accelerated Power Development Reform Program) and measures to simplify expenditure management, including addressing what is widely regarded as an unhelpful division of budgetary resources into "plan" and "non-plan", and rationalizing the management of Centrally Sponsored Schemes. ${ }^{54}$

\section{Debt and Deficit Projections to 2006/07}

General government debt and deficits are projected to the end of the Tenth Plan period, 2006/07, under two scenarios: a base case with no reform; and a reform case. The reform case is driven by priorities emerging from the above analysis and centers around revenue mobilization, the re-focusing of a part of food and fertilizer subsidies toward rural infrastructure and the elimination of power sector losses. ${ }^{55}$

Box 2 summarizes the assumptions underpinning the two scenarios. The reform scenario also assumes that the fiscal reforms are supplemented with structural reforms to spur growth. ${ }^{56}$ Debt projections are based on Annex 2, equation (1).

\footnotetext{
${ }^{53}$ States like Karnataka, Tamil Nadu, Kerala and Punjab.

${ }^{54}$ For details, see World Bank (2003) pages 27-28.

${ }^{55}$ As Mihir Rakshit has noted in comments, these reforms do not derive from an optimal fiscal program. In particular, no change in monetary policy is assumed, for example, a discontinuation of the sterilization of capital inflows which could increase seignorage by enlarging the monetary base. See also Rakshit (2000). Nevertheless, the projections here show that a small set of well-defined reforms can have a major positive impact by the end of the Tenth Plan period.

${ }^{56}$ For a detailed discussion of structural reforms, see World Bank (2003).
} 


\section{Box 2: Assumptions Underlying Debt/Deficit Projections}

The initial level of general government debt is 86 percent of GDP, its level at the end of 2002/03 plus 0.8 percent of GDP proposed for bailouts in connection with UTI, IDBI and IFCI.

The primary deficit of the general government stays at 3.5 percent of GDP in the base case, a little below its average level over the past six years. ${ }^{57}$ In the reform scenario, the primary deficit goes down linearly from 3.5 percent of GDP to 0.2 percent by the last year. This comes from raising central government revenue by 1.7 percentage points and state revenues by 0.7 percentage points by the terminal year; eliminating the petroleum subsidy of 0.4 percent of GDP; and eliminating the portion of the power subsidy already included in the state government budgets ( 0.5 percent of GDP out of a total of 1.5 percent of GDP, see below). It is assumed that taxes rise as a result of eliminating exemptions, widening the tax net to include services and implementing the state VAT.

Food and fertilizer subsidies amount to about 1.4 percent of GDP. Under reforms, 0.5 percent of GDP is maintained as a minimum social safety net; the balance of 0.9 percent is phased out while productivity-enhancing investments in agriculture, such as rural infrastructure and agricultural $\mathrm{R} \& \mathrm{E}$, increase by the same amount. There is no change in the base case.

SEB losses (portion not included in budget) remain 1 percent of GDP in the base case and go linearly to zero by the terminal year as a result of aggressive power sector reforms in the reform scenario.

Divestment receipts remain 0.5 percent of GDP in both scenarios.

Guarantees (contingent liabilities, CL) accumulated as of end 2002/03 devolve at the rate of 1 percent of GDP per year in both scenarios.

Growth, real interest rates and inflation based on the GDP deflator (percent) are as follows ${ }^{58}$ :

Growth (base) $)^{59}$

Growth (reform)

Real interest rate (both)

Inflation (both)

\begin{tabular}{cc}
$2003 / 04$ & $2004 / 05$ \\
5.5 & 5.0 \\
5.5 & 7.0 \\
6.3 & 6.2 \\
2.0 & 2.0 \\
\hline
\end{tabular}

A comment is in order on the real interest projection, which is common to both scenarios. The real interest rate which emerges will depend upon the nominal interest rate and inflation. The nominal interest rate will be determined by a weighted average of the interest rate on the preexisting debt stock and that on new borrowings. The implied nominal interest rate paid by the government was 8.6 percent in 2002/03. ${ }^{60}$ We assume that the marginal nominal interest rates are 7, 8, 9 and 9 percent respectively for the remaining four years of the Tenth Plan period and that 15 percent of the debt stock matures every year. Given the strong influence of the global interest rate cycle on Indian interest rates, there is no good reason to assume that one scenario will have dramatically different interest rates from the other over the next few years; further, the higher demand on the credit market for financing the much larger deficit in the base case will be offset to some extent by rising private credit demand in the reforms case as growth picks up. Similarly,

\footnotetext{
${ }^{57}$ The primary deficit incorporates seigniorage in the form of RBI profits and dividends, which enter non-tax revenue.

${ }^{58}$ The 8 percent Tenth Plan target would imply a growth rate of 8.9 percent per year over the remaining years of the Tenth Plan period, which seems unattainable at this point. The base case assumes a compound average growth rate of 5 percent during the Tenth Plan period and the reform scenario, 6.5 percent, reaching 8 percent in the terminal year.

${ }^{59}$ We also report results with a 6.5 percent growth rate assumption for 2003/04, given the present upbeat mood.

${ }^{60}$ This is obtained by adding the real growth rate to the implied difference between the real interest rate and growth rate shown in Figure 2 and then inflating by the implicit GDP deflator for 2002/03.
} 
the inflation environment is likely to be benign, and we assume that the implicit GDP deflator is 2 percent every year. ${ }^{61}$

The debt/GDP trajectories under the two scenarios are presented in Figure 4. In the base case, the general government debt/GDP ratio reaches 110 percent by the end of the Tenth Plan period. In the reforms scenario, it reaches 92.5 percent after peaking at 93 percent in 2005/06. These results are being driven by the general government primary deficit, SEB losses and the calling of guarantees, and underline the need for implementing fiscal and structural reforms. The broken lines are debt/GDP excluding contingent liabilities, $(\mathrm{CL}=0)$, which would lower the debt/GDP ratio to 106 percent by 2006/07 in the base case and 89 percent in the reforms case.

Figure 4: Government Debt/GDP Ratio Projected to 2006/07

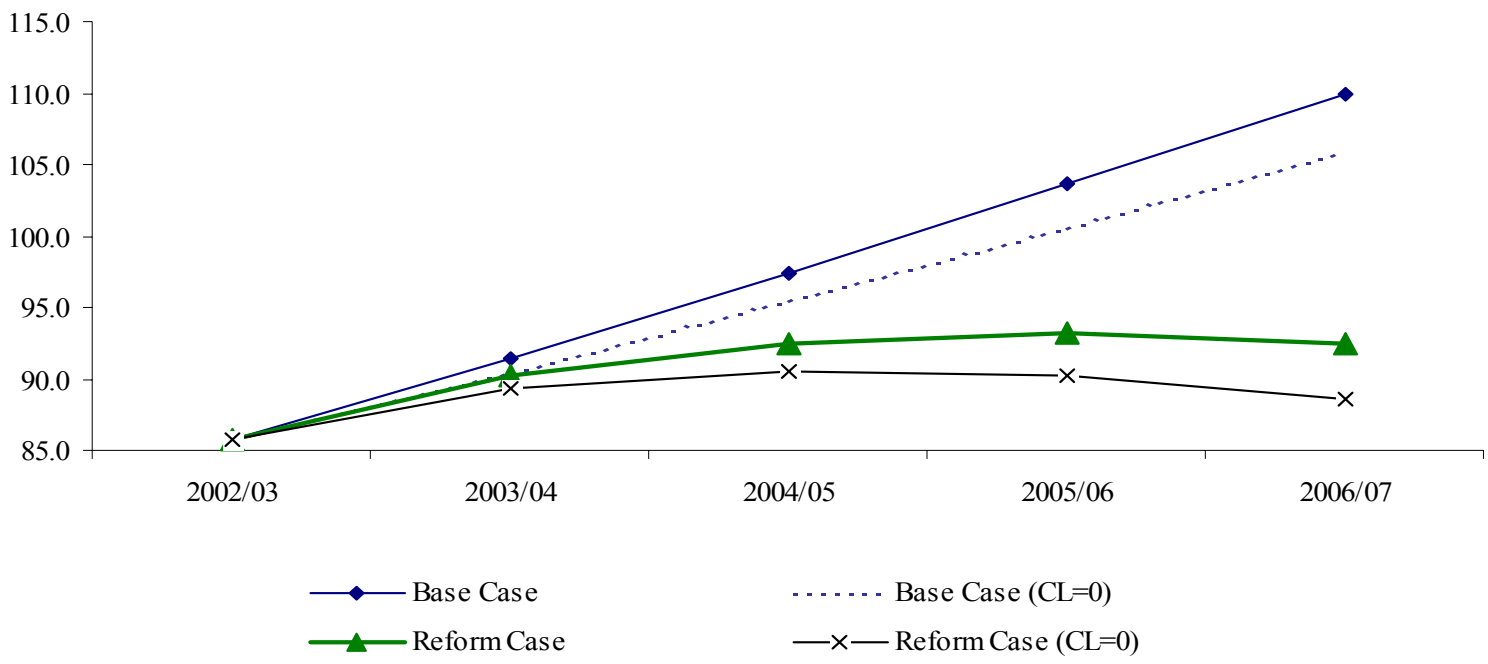

Annex 3 summarizes the methodology used to project the general government gross fiscal deficit. The results are shown in Figure 5. For this exercise, the calling of guarantees is ignored in projecting debt and hence interest payments $(C L=0)$. While the uncovered portion of SEB losses (the part not explicitly included in state government budgets, see Box 2) is factored into the projection of debt levels and hence interest payments, they are not included in Figure 5 for comparability with present deficit reporting practices; thus, the "true" picture especially in the base case is likely to be worse than depicted in Figure 5.

\footnotetext{
${ }^{61}$ The scenarios presented in World Bank (2003) assumed that the convergence of real interest rates to the growth rate observed after 1997/98 would hold over the rest of the Tenth Plan period, and further, focused on CPI inflation rather than that measured by the implicit GDP deflator. The net effect is that projected nominal interest rates and therefore fiscal deficits are much higher than those reported here, especially under reforms.
} 
Figure 5: Projected General Government Fiscal Deficits

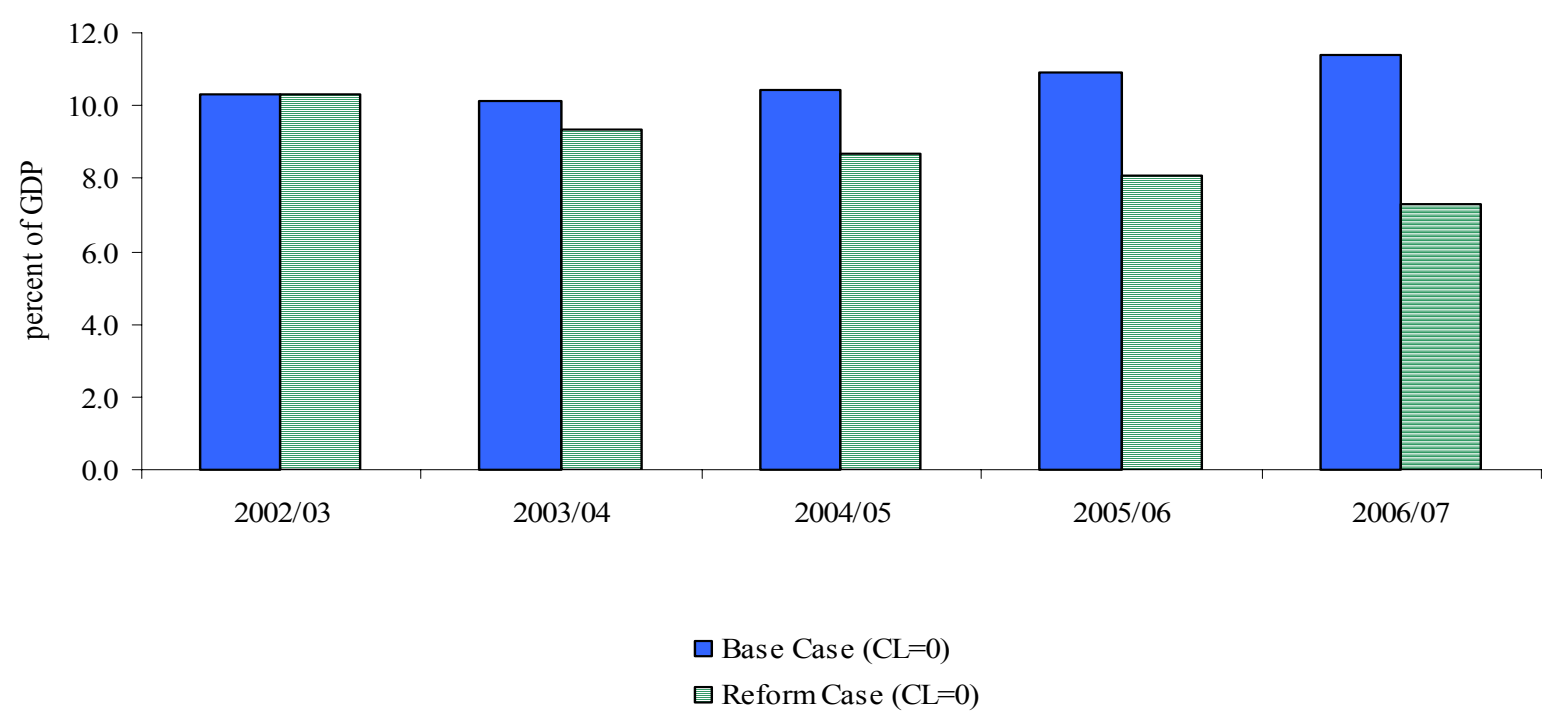

In the base case, deficits rise to 11.4 percent of GDP by 2006/07. Under reforms, deficits fall steadily to just over 7 percent of GDP. While there is not much difference in interest payments between the two scenarios initially, (because of the high level of initial debt, the absence of primary fiscal surpluses even in the reform scenario and similar levels of nominal interest rates), a substantial difference emerges by 2006/07. Moreover, the reform scenario permits 0.9 percentage points of GDP more of capital and developmental expenditure by the 2006/07 as a result of refocusing subsidies towards rural infrastructure and agricultural R\&E; and subsidies are reduced to a minimum food social safety net of 0.5 percent of GDP under reforms compared to 2.3 percentage points in the base case.

Given the upbeat mood about growth for 2003/04, we also ran a base case with a growth rate of 6.5 percent for 2003/04, with the other rates unchanged, i.e., there is a rebound from the low growth of 2002/03 but the trend rate does not rise. This has only a marginal impact: the debt/GDP ratio is 1 percentage point lower by 2006/07 and the fiscal deficit drops to 11.3 percent of GDP compared to 11.4 percent otherwise. This underlines that one year of good growth is not going to alleviate the fiscal situation and that a sustained effort is unavoidable. ${ }^{62}$

What happens to revenue deficits? Under reforms, the increase in revenues $(+2.4$ percentage points of GDP), elimination of petroleum subsidy plus the portion of SEB losses already incorporated in state budgets ( 0.9 percentage points) and refocusing part of food and fertilizer subsidies towards capital spending ( 0.9 percentage points) act to reduce the general government revenue deficit by about 4.2 percentage points of GDP by 2006/07. Interest payments rise slightly, from 6.6 percent of GDP in the base year to about 7 percent of GDP by 2006/07. Thus, the net reduction in the revenue deficit will be close to 4 percentage points of GDP, not enough to eliminate it but reducing it to about 2 percent of GDP compared to current levels of over 6 percent. Without reform, the debt burden and ratio of interest payments to revenue will become unmanageable and revenue deficits will rise further. This is likely to fuel inflationary expectations and raise interest rates. This will in turn dampen investment and lead to anemic growth.

${ }^{62}$ We are grateful to Suresh Tendulkar for making this point. 


\section{Concluding Remarks}

We have presented evidence showing that public finance fundamentals have deteriorated after 1997/98 even when compared to the period that preceded the 1991 fiscal-BoP crisis. The recent record lows in interest rates have not softened this deterioration because of slowing growth and because public debt dynamics are driven by the average cost of the whole stock of debt, not just the marginal cost of new borrowings. Moreover, while low interest rates help at the margin, the low inflation environment that produced them hurts to the extent that high nominal interest rates on dated securities were contracted in past years.

While much of the recent emphasis in explaining the fiscal deterioration has been on the Fifth Pay Commission award, the elimination of financial repression and incomplete tax reforms have "cost" the exchequer a minimum of 2.5 percentage points of GDP over the 1990s. The thrust of the fiscal response so far has been to contain the gross fiscal deficit in the 10-11 percent of GDP range by cutting capital and development expenditure. This is a sub-optimal response from the perspective of long-run growth and poverty reduction. Against this background, the desire to crisis-proof by building up reserves and keep inflation low by targeting base money instead of making a fiscal adjustment has led to the emergence of a "loose fiscal-tight money" policy mix after 1997/98. This has also meant that the benefits from financial sector liberalization have not been forthcoming. Banks would naturally prefer to lend to the government at market-determined rates than make "risky" loans to the private sector. ${ }^{63}$ If India is to reap the benefits associated with greater financial liberalization, there must be a fiscal adjustment focused in the first instance on revenue mobilization and tax reform to compensate for the loss of revenues from financial repression and customs duties in order to lower the supply of government debt and create more space for the private sector. At the same time, power sector losses and guarantees extended by state governments for bonds issued by loss-making public enterprises have become a significant threat to state government finances. Moreover, the decline in interest rates over the past 18 months or so is unlikely to survive a recovery in the global economy. Therefore, a program of robust fiscal reform is needed to combat unsustainable public debt dynamics and help India achieve its long-run growth and poverty reduction targets.

To urge a phased "fiscal adjustment now", the paper presents debt projections under a base case with no reform, and an alternative reform case focusing on a small set of well-defined reforms. In the base case, the debt and interest burdens become unmanageable by the end of the Tenth Plan period, while under reform, deficits come down and the composition of spending greatly improves.

In conclusion, the paper has argued that India is unlikely to grow out of its debt problem in spite of today's low interest rates. To the contrary, a fiscal adjustment is needed to underpin faster growth. Even though it is difficult to develop the political momentum for reform in the absence of an impending crisis, the government has clearly recognized the need for fiscal adjustment through various initiatives and policy pronouncements. The challenge is to translate these concerns into a road map for fiscal adjustment. Doing so will create a better investment climate and help promote long-run growth and poverty reduction at the accelerated pace envisaged in the Tenth Plan document.

\footnotetext{
${ }^{63}$ Leading, in the memorable words of the Deputy Governor of the RBI to the advent of "lazy banking".
} 


\section{Annex 1: Background}

\section{India's 1991 BoP Crisis}

In 1991, India experienced a balance-of-payments (BoP) crisis which pushed it to the verge of default on its external debt. ${ }^{64}$ The crisis followed an acceleration in growth to 6 percent in the second half of the 1980s; but fiscal deficits bordering on 10 percent of GDP during this period fed into growing current account deficits. Fiscal deficits were financed in the main by a combination of financial repression and external borrowing, with relatively limited monetization to keep inflation low. As a result of the "twin deficits", public and external debt grew while reserves fell. External debt almost doubled from $\$ 35$ billion at the end of 1984/85 to \$69 billion at the end of 1990/91, with commercial borrowing and remittances of NRIs becoming increasingly important as the size of current account deficits exceeded available financing on concessional terms. This in turn meant rising dependence on more costly, shorter maturity financing and made India vulnerable to shocks, which came in the form of an oil price hike as a result of the 1990 Gulf War and a related disruption in worker remittances. By September 1990, net inflows from non-resident Indian (NRI) deposits had become negative and access to commercial borrowing was growing costly and difficult. Export growth also weakened with slow growth in trading partners, the US in particular. By the end of January 1991, reserves had fallen to less than a billion dollars and debt service payments were maintained only by an administrative squeeze on imports and emergency financing from the IMF, including a drawdown of $\$ 1.8$ billion under the Compensatory Financing Facility and First Credit Tranche arrangement. Unstable coalition politics between the end of the Rajiv Gandhi Congress government in late 1989 and the installation of the Narasimha Rao Congress government in June 1991 made matters worse. India suffered a ratings downgrade in early 1991.

The response to the crisis included a large devaluation, an increase in interest rates and a program to implement a large cut in the center's fiscal deficit. Equally important was an intensification of the process of industrial delicensing and gradual trade liberalization (replacing quantitative restrictions with tariffs) which had begun in the second half of the 1980s. There was a push to drastically accelerate these reforms, with the focus then turning to tax reform, further trade liberalization (including tariff reductions) and financial sector reforms.

From the perspective of the this paper, the following points from the 1991 crisis are of interest: (i) The higher growth achieved in the second half of the 1980s was not destined to last. As RBI (2003a) notes, “... [it] was excessively leveraged through large fiscal deficits and build-up of external debt. In this sense, the growth before the reform was unsustainable." ${ }^{\prime 65}$ (ii) The crisis was caused by a combination of deteriorating public finance fundamentals and low international liquidity. Fiscal deficits spilled over into the balance of payments and depleted reserves, making India vulnerable to external shocks which came in the form of the 1990 Gulf War. The crisis thus stemmed from a combination of weak fundamentals and a confidence shock that shut off market borrowing access. Cerra and Saxena (2002) also argue that the rupee was overvalued in an equilibrium sense at the time of the crisis, the persistent depreciation of the real exchange rate over the second half of the 1980s notwithstanding. (iii) The crisis led to fiscal and structural reforms, which had tangibly positive results over the Eighth Plan period. (iv) India crucially managed to avoid a "credit event", i.e., a default and/or debt restructuring, which would have tarnished its record. While WPI inflation rose to 14 percent in 1991/92, it was quickly brought

\footnotetext{
${ }^{64}$ The discussion here draws from Acharya (2001), Cerra and Saxena (2002), Chopra et al. (1995) and Virmani (2001).
}

${ }^{65} \mathrm{RBI}$ (2003a) page I-1. 
under control. And (v) as emphasized by Acharya (2001) there was a conscious post-crisis decision to build up FX reserves and minimize dependence on external debt in financing the deficit as part of a crisis-proofing strategy.

\section{Debt Sustainability through the 1990s}

Sustainability means the fiscal policy is feasible, i.e., no problems are seen in relation to debt servicing in the foreseeable future under prevailing fiscal policies. ${ }^{66}$ The idea of solvency is simply that the present discounted value of future fiscal primary surpluses (revenues minus noninterest expenditure) plus seignorage exceed the initial level of debt. ${ }^{67}$ This condition applies when the real interest rate exceeds the growth rate, which, in the absence of financial repression, is typically the case. Discussions of sustainability and solvency can be conducted at various levels of technical complexity. Be that as it may, tests throughout the 1990s of the solvency condition -- based on examining the stationarity of the time series of the nominal debt stock discounted back to some historical point in time -- were unable to reject the hypothesis that India's public debt was on an explosive path under prevailing fiscal policies. The operative phrase is "under prevailing policies". For example, in a seminal paper, Buiter and Patel (1992) found, using data from 1970/71 to $1987 / 88$, that the discounted public debt was nonstationary. They warned, in the first draft of the same paper which was completed before the $1991 \mathrm{BoP}$ crisis, that without a reduction in the primary fiscal deficit, India was heading for a fiscal crisis that could exhaust reserves and lead to emergency IMF funding. While this came to pass, the 1991 crisis led to well-documented fiscal and structural reforms, which led to an acceleration of growth and a decline in the debt/GDP ratio during the Eighth Plan period (1992/93-1996/97). Thus, the "prevailing fiscal policies" changed after the 1991 crisis, but not for long.

Serven (1996) re-examined the solvency of the Indian public sector motivated by the observation that by 1996, the fiscal adjustment occasioned by the 1991 crisis appeared to be losing steam. The paper concluded along the lines of Buiter and Patel that debt was on an explosive path. An additional concern was that, with the introduction of the auction system for Treasury Bills and dated securities in 1992/93, interest rates would rise with the growing volume of public debt, placing it on an even faster upward trajectory. Serven presented evidence showing that the average interest rate on government debt was rising, which meant that at the margin, interest rates were rising even faster, i.e., newly-issued debt was carrying a higher interest rate than the inherited debt stock, pushing up the average rate of interest paid. Serven argued that it was only a matter of time before the marginal and average interest rates converged, with a sizable impact on deficits and debt. In addition, the elimination or reduction in financial repression as a result of lowering the cash reserve ratio and statutory liquidity ratio for banks combined with a move to market-determined prices for government securities would boost interest rates. ${ }^{68}$ All this would mean three things: (i) interest payments would consume a growing share of revenues and reduce the resources available for public spending on infrastructure and the social sectors; (ii) a growing burden would fall on monetary policy to keep inflation within target levels. In other words, there was the danger that a "loose fiscal-tight money" policy would emerge; and (iii) as debt and interest payments rose, the fiscal latitude to deal with unanticipated shocks, e.g., a bad monsoon, would be severely curtailed.

\footnotetext{
${ }^{66}$ See Reynolds (2001), which discusses various notions of sustainability and solvency.

${ }^{67}$ Debt, primary fiscal surpluses and seignorage are all expressed as fractions of GDP and the appropriate discount rate is the real (nominal) interest rate minus the real (nominal) growth rate.

${ }^{68}$ Revenues from financial repression were estimated by Giovannini and de Melo (1993) as close to 3\% of GDP per year over 1980-85. Kletzer and Kohli (2001) come up with higher numbers using the same methodology.
} 
The point about interest rates rising as financial repression fell was taken up in Reynolds (2001), to reinforce the case for a fiscal adjustment conducive to growth. The paper noted that Indian public finances were benefiting from growth rates that exceeded interest rates, but this difference would erode and even reverse as domestic financial liberalization progressed and the volume of debt grew. The situation would worsen further from the slowing of growth as a result of the crowding out of private investment by rising interest rates and the increased financing needs of the deficit. The paper concluded that absent a planned fiscal adjustment, an adjustment would be forced by rising real interest rates which would slow growth and poverty reduction, and by growing current account deficits creating a vulnerable external position. In other words, there would be a repetition of the 1991 fiscal-BoP crisis. ${ }^{69}$

Much of what was anticipated in the preceding papers has occurred after 1997/98 with one exception: a solid cushion of foreign exchange reserves has been built up. However, this does not diminish the urgency of fiscal consolidation and reform. By aiming to build up reserves and keep inflation low without an adequate fiscal adjustment, India is at risk of painting itself into a substandard growth corner.

\footnotetext{
${ }^{69}$ Cashin et al. (2001) compute a debt stock consistent with tax smoothing and then examines the difference between actual debt and the "smoothed" debt. The authors find the difference to be non-stationary and hence indicative of an explosive debt path. (A potential problem with this approach is that the sample period overlaps with the tax and financial sector reforms following the 1991 crisis, which led to a reduction both of direct tax revenues and implicit taxes from financial repression. This hopefully temporary decline in taxes would both interfere with any notion of tax smoothing and lead to a rise in debt.)
} 


\section{Annex 2: Government Debt Dynamics}

Debt dynamics are driven by primary deficits and interest payments, which add up to the gross fiscal deficit. As debt is usually expressed as a ratio of GDP, growth also comes into play. Equation (1) is the standard difference equation for government debt:

$$
d_{t}-d_{t-1}=p d_{t}-D R_{t}+F_{t}+\frac{\left(r_{t}-g_{t}\right)}{\left(1+g_{t}\right)} d_{t-1}
$$

where $d$ is the government debt-to-GDP ratio, $p d$ is the ratio of the primary deficit to GDP, $D R$ is divestment (privatization) receipts, $F$ stands for the new flow of debt issued in connection with financial sector bailouts (both as ratios of GDP), $r$ is the real interest rate, $g$ is the real growth rate and the subscript refers to fiscal years. ${ }^{70}$ The LHS of (1) is the increase in the debt-GDP ratio relative to the previous year. It is explained by the primary deficit (pd) less divestment revenues (DR - as these lower borrowing requirements) plus financial sector bailout costs ( $\mathrm{F}$ - as these necessitate more debt issue). The last term captures the interaction between interest rates and growth: the interest rate determines the interest payment on public debt while growth acts to lower the ratio of GGD to GDP.

The implied difference between the real interest rate and real growth rate for a given year, $\left(r_{t}-g_{t}\right)$, can be obtained through straightforward rearrangement of the terms in equation (1).

The key points to note about the real interest rate thus obtained are (i) it reflects all capital gains and losses through real exchange rate changes and inflation on the outstanding stocks of foreign currency-denominated and domestic currency debt respectively; and (ii) the implicit GDP deflator is effectively being used to convert nominal to real.

\footnotetext{
${ }^{70}$ The last term on the RHS can be equivalently written $\frac{\left(i_{t}-G_{t}\right)}{\left(1+G_{t}\right)} d_{t-1}$, where $i$ is the nominal interest rate on GGD
} and $G$ is the nominal rate of growth of GDP. 


\section{Annex 3: Projection of General Government Fiscal Deficit}

The formula is:

$$
F D_{t}=P D_{t}+i_{t}^{n} D_{t-1},
$$

where $F D$ is the nominal fiscal deficit of the general government, $P D$ is the nominal primary deficit, $i_{t}^{n}$ is the nominal interest rate in fiscal year $\mathrm{t}$ and $D$ is the nominal level of debt. Note that:

- while it would strictly be conceptually correct, we ignore SEB losses in computing PD

- $\quad$ we use $D$ ignoring the calling of guarantees, but reflecting SEB losses.

The reasons for ignoring SEB losses (although their effect is captured in debt levels and hence interest payments) is for comparability with existing reporting practices for general government fiscal deficits (which do not incorporate either SEB losses or make any provision for guarantees).

Dividing both sides of the above equation by $G D P_{t}$ gives:

$$
\begin{aligned}
& f d_{t}=p d_{t}+i_{t}^{n} \frac{D_{t-1}}{G D P_{t-1}} \frac{G D P_{t-1}}{G D P_{t}}, \text { or: } \\
& f d_{t}=p d_{t}+\frac{i_{t}^{n}}{\left(1+G_{t}\right)} d_{t-1}, \text { where: }
\end{aligned}
$$

$G$ is the nominal growth rate of GDP. Using the standard formulas for the nominal interest rate and nominal growth rate gives the full formula:

(2) $\quad f d_{t}=p d_{t}+\frac{\left(1+r_{t}\right)\left(1+\pi_{t}\right)-1}{\left(1+g_{t}\right)\left(1+\pi_{t}\right)} d_{t-1}$, where:

$\pi_{t}$ is the inflation rate (the other variables are the same as defined in Annex 2). 


\section{References}

Acharya, Shankar. 2001. "India's Macroeconomic Management in the Nineties." Indian Council for Research on International Economic Relations, New Delhi.

_ 2002a. "Macroeconomic Management in the Nineties." Economic and Political Weekly, April.

_. 2002b. "India's Medium-Term Growth Prospects." Economic and Political Weekly, July.

Ahluwalia, Montek S. 2002a. "India's Vulnerability to External Crisis: An Assessment." In Macroeconomics and Monetary Policy: Issues for a Reforming Economy. Essays in Honor of C. Rangarajan, eds. Montek Ahluwalia, S.S. Tarapore and Y.V. Reddy, OUP

_. 2002b. "Economic Reforms in India: A Decade of Gradualism." Journal of Economic Perspectives, forthcoming.

Aizenman, Joshua, 2003. “On the Hidden Links Between Financial and Trade Opening.” Working Paper 9906. National Bureau of Economic Research, Cambridge, MA.

Buiter, Willem, and Urjit Patel. 1992. "Debt, Deficits and Inflation: An Application to the Public Finances of India." Journal of Public Economics 47: 171-205.

Bossone, Biagio, Sandeep Mahajan and Farah Zahir, 2003. "Financial Infrastructure, Group Interests, and Capital Accumulation- Theory, Evidence, and Policy”. IMF Working Paper, Washington, D.C.

Bossone, Biagio and Farah Zahir, 1999. "Non Bank Financial Companies in India". Background paper "India's Banking System: Moving Towards Best Practices". Report No. 20169-IN, Finance and Private Sector, South Asia Region, World Bank, Washington, DC.

Cashin, P., N. Olekalns, and R. Sahay. 2001. "Tax Smoothing, Financial Repression and Fiscal Deficits in India." In Tim Callen, Patricia Reynolds, and Christopher Towe, eds., India at the CrossroadsSustaining Growth and Reducing Poverty. International Monetary Fund, Washington, D.C.

Chandrasekhar, C.P. 2000. "Economic Reform and the Budget." Economic and Political Weekly, April 1,2000, 1140-1142.

Chang, Roberto, and Andres Velasco. 1998. The Asian Liquidity Crisis. NBER Working Paper 6796. Washington, D.C.: National Bureau of Economic Research.

Chopra, Ajai, Charles Collyns and Richard Hemming. 1995. "India: Economic Reform and Growth." Occasional Paper 134. Washington: International Monetary Fund.

CRISIL (Credit Rating and Information Services of India Limited). 2002. "Mounting State Government Guarantees - Fiscally Unsustainable.” July.

Deininger, Klaus, and D. Umali-Deininger. 2001. “Towards Greater Food Security For India's Poor: Balancing Government Intervention And Private Competition.” Agricultural Economics 25: 32135 .

_. Forthcoming. "Targeted Public Distribution System: Is it Reaching the Poor?” World Bank.

Flood, Robert, and Olivier Jeanne. 2000. “An Interest Rate Defense of a Fixed Exchange Rate?” IMF Working Paper WP/00/159. International Monetary Fund, Washington, D.C..

Goswami, Omkar, and David Dollar. 2002. "Competitiveness of Indian Manufacturing: Results from a Firm Level Survey.” Confederation of Indian Industries, New Delhi.

Govinda Rao, M. 2000. “Invisible Transfers in Indian Federalism.” Public Finance, 52 (3, 4): 429-48.

Hanson, J. 2002. "Improving Indian Banks Performance.” Paper presented at the Goa Conference on Adapting India's Financial Sector to a Globalized World, October 31 - November 2, 2002, Goa.

IMF (International Monetary Fund). 2002. India: Selected Issues and Statistical Appendix. IMF Country Report 02/193. 
India, Ministry of Finance. 1999. Economic Survey 1998-99. New Delhi.

- 2001. Economic Survey 2000-01. New Delhi.

—. 2002a. Economic Survey 2001-02. New Delhi

—. 2002b. External Debt Status Report. August. New Delhi.

2003. Economic Survey, 2002-03. New Delhi.

India, Planning Commission 2001. “Approach Paper to the Tenth Five Year Plan 2002-2007.” New Delhi. . 2002. "Annual Report on the Working of SEBs and Electricity Departments." New Delhi.

Kapur, Devesh, and Urjit R. Patel. 2003. "Large Foreign Currency Reserves: Insurance for Domestic Weakness and External Uncertainities?" Economic and Political Weekly 38(11): 1047-53.

Kelkar, V.J. 2002. Report of the Task Force on Direct-Indirect Taxes. New Delhi: Akalank Publications.

Kletzer, Kenneth, and Renu Kohli. 2001. "Financial Repression and Exchange Rate Management in Developing Countries: Theory and Empirical Evidence for India." IMF Working Paper WP/01/103. Washington, D.C.

Lahiri, Ashok, and R. Kannan. 2002. "India's Fiscal Deficits and Their Sustainability in Perspective." In India-Fiscal Policies to Accelerate Economic Growth. Green cover Report 2473IN. South Asia Region, Poverty Reduction and Economic Management Unit, Washington, D.C.

Lal, Deepak, Suman Bery and Devendra Kumar Pant. 2003. "The Growth Slowdown: Real Exchange Rate Misalignment, Fiscal Deficits and Capital Flows". Draft, NCAER, New Delhi.

Mohan, Rakesh. 2003. "Transforming Indian Banking: In Search of a Better Tomorrow." Reserve Bank of India Bulletin. Mumbai.

Obstfeld, Maurice, and Alan M. Taylor. 1998. "The Great Depression as a Watershed: International Capital Mobility in the Long Run.” In M.D. Bordo, C.D. Goldin and E. N. White, eds., The Defining Moment: The Great Depression and the American Economy in the Twentieth Century. Chicago, University of Chicago Press.

Patnaik, Ila, and Deepa Vasudevan. Undated. "Trade Misinvoicing and Capital Flight from India" National Council of Applied Economic Research, New Delhi.

Rakshit, Mihir. 2000. "On Correcting Fiscal Imbalances in the Indian Economy : Some Perspectives." Money and Finance (July-Sept 2000) pp.19-56.

Reddy, Y.V.. 2002. "India's Foreign Exchange Reserves: Policy, Status and Issues.” Economic and Political Weekly. May 18, 2002, pp. 1906-1917.

Reserve Bank of India. 2002a. Annual Report 2001-02. Mumbai.

- 2002b. Report on Trends and Progress of Banking in India 2001-02. Mumbai.

- 2002c. Report on Currency and Finance 2000-01. Mumbai.

- 2001a. Annual Report 2000-01. Mumbai.

-2001b. Handbook of Statistics of Indian Economy 2001. Mumbai.

_.2001c. Reserve Bank of India Monthly Bulletin January 2002. Mumbai.

-2003a. Report on Currency and Finance 2001-02. Mumbai.

_. 2003b. "Accretion to Foreign Exchange Reserves in India: Sources, Arbitage and Costs." Press Release January. Mumbai.

-2003c. Monthly Bulletin. January. Mumbai.

-2003d. State Finances: A Study of Budgets of 2002-03. February. Mumbai. 
2003e. Report of the Group to Assess the Fiscal Risk of State Government Guarantees. July. Mumbai.

- Report on Trend and Progress of Banking in India, various years.

Reynolds, Patricia. 2001. "Fiscal Adjustment and Growth Prospects in India." In Tim Callen, Patricia Reynolds, and Christopher Towe, eds., India at the Crossroads: Sustaining Growth and Reducing Poverty. Washington, D.C.: International Monetary Fund.

Reinhart, Carmen, Kenneth Rogoff and Miguel Savastano. 2003. "Debt Intolerance.” Forthcoming, Brookings Papers on Economic Activity.

Sargent, Thomas J., and Neil Wallace. 1981. "Some Unpleasant Monetaristic Arithmetic." Federal Reserve Bank of Minneapolis Quarterly Review 5(3): 1--17.

Serven, Luis. 1996. "Fiscal Deficits and Public Sector Solvency in India". Draft. The World Bank.

Srinivasan, T.N. 2001. “India's Fiscal Situation: Is a Crisis Ahead?” Working Paper 92. Stanford University, Center for Research on Economic Development and Policy Reform, Palo Alto, Ca.

Williamson, John, and Roberto Zagha. 2002. "From Slow Growth to Slow Reform?” Paper presented at Stanford University, June 3-4, Palo Alto, California.

World Bank. 2000. India: Reducing Poverty, Accelerating Development. World Bank Country Study. New Delhi: Oxford University Press.

—. 2001a. "India Improving Household Food and Nutrition Security." Report No. 20300-IN. Washington, D.C.

—.2001b. "India: Power Supply to Agriculture Vol I-IV.” Report 22171-IN, SASEI South Asia Energy and Infrastructure Unit, Washington, D.C.

World Bank. 2002a. "India: Fiscal Policies to Accelerate Economic Growth." Green Cover Report 2473IN. South Asia Region, Poverty Reduction and Economic Management Unit, Washington, D.C.

_. 2002b. "India: Power Sector Reforms and the Poor." South Asian Energy and Infrastructure Unit, World Bank, Washington, D.C.

World Bank. 2003. "India: Sustaining Reform, Reducing Poverty.” World Bank Development Policy Review. New Delhi. Oxford University Press.

Zahir, Farah. 2002. "India: Trends and Pattern of Public Spending in Uttar Pradesh", World Bank Policy Note, Washington, D.C.

wb239892

C: \Documents and Settings|wb239892\Desktop\India -Why Fiscal Adjustment Dec 10 2003-FINAL.doc

February 23, 2004 11:04 AM 